\title{
Invited review: Remediation strategies for mycotoxin control in feed
}

\author{
Meng Liu', Ling Zhao', Guoxin Gong ${ }^{1}$, Lei Zhang ${ }^{1}$, Lei Shi', Jiefan Dai ${ }^{2}$, Yanming Han ${ }^{3}$, Yuanyuan $\mathrm{Wu}^{3}$, \\ Mahmoud Mohamed Khalit ${ }^{4}$ and Lvhui Sun ${ }^{1 *}$
}

\begin{abstract}
Mycotoxins are secondary metabolites of different species of fungi. Aflatoxin $B_{1}\left(A F B_{1}\right)$, deoxynivalenol (DON), zearalenone (ZEN) and fumonisin $B_{1}\left(F B_{1}\right)$ are the main mycotoxins contaminating animal feedstuffs. These mycotoxins can primarily induce hepatotoxicity, immunotoxicity, neurotoxicity and nephrotoxicity, consequently cause adverse effects on the health and performance of animals. Therefore, physical, chemical, biological and nutritional regulation approaches have been developed as primary strategies for the decontamination and detoxification of these mycotoxins in the feed industry. Meanwhile, each of these techniques has its drawbacks, including inefficient, costly, or impractically applied on large scale. This review summarized the advantages and disadvantages of the different remediation strategies, as well as updates of the research progress of these strategies for $\mathrm{AFB}_{1}, \mathrm{DON}, \mathrm{ZEN}$ and $\mathrm{FB}_{1}$ control in the feed industry.
\end{abstract}

Keywords: Animal health, Feed, Mycotoxin, Performance, Remediation strategies

\section{Introduction}

Mycotoxins are secondary metabolites of various species of fungi that can cause chronic or acute toxicity in animals. Although over 500 mycotoxins have been identified, those of importance in feed safety are primarily produced by the five fungal genera Aspergillus, Fusarium, Penicillium, Claviceps and Alternaria [1-5]. Aflatoxin $\mathrm{B}_{1}\left(\mathrm{AFB}_{1}\right)$, deoxynivalenol $(\mathrm{DON})$, zearalenone (ZEN) and fumonisin $\mathrm{B}_{1}\left(\mathrm{FB}_{1}\right)$ are well-known as the main mycotoxins contaminating animal feedstuffs, such as corn, barley, wheat, peanuts, peas, nuts, millet, forage, and their by-products [3-6]. The toxicity of these mycotoxins varies depending on their chemical structure (Fig. 1). The most toxic mycotoxin is $\mathrm{AFB}_{1}$, mainly produced by Aspergillus, which is classified as a Group one carcinogen [7]. It displays hepatotoxic, immunotoxic, mutagenic, carcinogenic and teratogenic characteristics in

\footnotetext{
* Correspondence: Ivhuisun@mail.hzau.edu.cn

'Hubei Hongshan Laboratory, College of Animal Science and Technology, Huazhong Agricultural University, Wuhan 430070, Hubei, China

Full list of author information is available at the end of the article
}

many animal species [8-11]. Notably, all of DON, ZEN and $\mathrm{FB}_{1}$ are primarily produced by Fusarium molds [5, $12]$. DON, a type $B$ trichothecene, can induce anorexia, vomiting, and endanger intestinal and immune functions in different animals by inhibiting the synthesis of nucleic acids and proteins [13-16]. ZEN has a similar structure to estrogen and thus competing with $17 \beta$-estradiol for estrogen receptor binding, consequently leading to fertility and reproductive disorders in livestock $[16-19] . \mathrm{FB}_{1}$ is the most plentiful fumonisins, which can cause hepatotoxicity, neurotoxicity, nephrotoxicity, immunotoxicity, developmental toxicity and cancer in humans and animals [20].

Mycotoxins have been proven to have significant effects on animal health, performance, as well as quality and safety of products, this led to intensive studies over the past few decades on counteracting methods for mycotoxins control in feedstuffs and feed. Generally, physical, chemical, biological and nutritional regulation approaches have been developed as the main strategies for the detoxification of mycotoxins in the feed industry

(c) The Author(s). 2022 Open Access This article is licensed under a Creative Commons Attribution 4.0 International License, which permits use, sharing, adaptation, distribution and reproduction in any medium or format, as long as you give appropriate credit to the original author(s) and the source, provide a link to the Creative Commons licence, and indicate if changes were made. The images or other third party material in this article are included in the article's Creative Commons licence, unless indicated otherwise in a credit line to the material. If material is not included in the article's Creative Commons licence and your intended use is not permitted by statutory regulation or exceeds the permitted use, you will need to obtain permission directly from the copyright holder. To view a copy of this licence, visit http://creativecommons.org/licenses/by/4.0/ The Creative Commons Public Domain Dedication waiver (http://creativecommons.org/publicdomain/zero/1.0/) applies to the data made available in this article, unless otherwise stated in a credit line to the data. 
<smiles>COc1cc2c(c3oc(=O)c4c(c13)CCC4=O)C1C=COC1O2</smiles><smiles>CC(=C(C)C(C)(C)C(C)(C)C)c1c(C)c(O)c(C)c(O)c1C(=O)C(C)(C)C(C)(C)C(=O)C(C)(C)C(C)(C)C</smiles>

ZEN<smiles>CCCC(C)CC(OC(=O)CC(CC(=O)O)C(=O)O)C(CC(C)CC(O)CCCCC(O)CC(O)C(C)N)OC(=O)CC(CC(=O)O)C(=O)O</smiles>

$\mathrm{FB}_{1}$

Fig. 1 Structural diversity of $A F B_{1}, D O N, Z E N$ and $F B_{1}$. AFB 1 : Aflatoxin $B_{1}$; DON: deoxynivalenol ; $Z E N$ : zearalenone; FB $B_{1}$ fumonisin $B_{1}$

[21-26]. Nevertheless, many techniques have been proven to be inefficiency, costly, or impractically applied on large scale $[21,22]$. The purpose of this review was to summarize the advantages and disadvantages of the various detoxification strategies, as well as update the research progress of these strategies for $\mathrm{AFB}_{1}, \mathrm{DON}, \mathrm{ZEN}$ and $\mathrm{FB}_{1}$ control in the feed industry.
The strategies of mycotoxin reduction and detoxification Physical methods

Decontamination of mycotoxin by physical techniques mainly includes sorting and separation, washing, solvent extraction, heating, irradiation, and adsorption [27, 28]. The commonly used methods of physical detoxification of mycotoxins are summarized in Table 1.

Table 1 Summary of physical methods for mycotoxins decontamination ${ }^{a}$

\begin{tabular}{|c|c|c|c|}
\hline Methods & Commonly used measures and reagents & Decontamination efficiency & References \\
\hline $\begin{array}{l}\text { Sorting and } \\
\text { separation }\end{array}$ & $\begin{array}{l}\text { Sieving, aspiration, gravity separation, photoelectric } \\
\text { separation, image processing }\end{array}$ & $\begin{array}{l}\text { Removed at least } 51 \%, 63 \%, 93 \% \text { of AFs, trichothecenes } \\
\text { and fumonisins from the shelled white maize. }\end{array}$ & {$[27]$} \\
\hline $\begin{array}{l}\text { Washing and } \\
\text { solvent } \\
\text { extraction }\end{array}$ & $\begin{array}{l}\text { Washing, solvent extraction (methanol, ethanol, hexane, } \\
\text { acetonitrile, isopropanol and aqueous acetone etc.) }\end{array}$ & $\begin{array}{l}\text { Removed aflatoxins, trichothecenes, ZEN and } \\
\text { fumonisins by } 51-72 \%, 64-69 \%, 2-61 \% \text { and } 73-74 \% \\
\text { from the grains through floating and washing with water. }\end{array}$ & {$[25,27,29]$} \\
\hline Heating & High temperature, high voltage & $\begin{array}{l}\text { Decomposited } 78-88 \% \text { of } A F B_{1} \text { in rice by cooking } \\
\text { with pressure }\left(0.10 \mathrm{MPa} \text { ) at } 160{ }^{\circ} \mathrm{C} \text { for } 20 \mathrm{~min} \text {. }\right. \\
\text { Destroyed } 90 \% \text { of DON or ZEN in barely power } \\
\text { at } 220^{\circ} \mathrm{C} \text { in } 11 \text { or } 85 \mathrm{~min} \text {. } \\
\text { Reduced } 80 \% \mathrm{FB}_{1} \text { while cooking rice at } 100{ }^{\circ} \mathrm{C} \text { for } 10 \mathrm{~min} \text {. }\end{array}$ & {$[30-32]$} \\
\hline Irradiation & $\begin{array}{l}\text { X-rays, } \mathrm{Y} \text {-rays and electron beam, } \\
\text { ultraviolet rays, infrared and microwave }\end{array}$ & $\begin{array}{l}\text { Reduced } 22.0-90.7 \% \text { of } A F B_{1} \text { by irradiation. } \\
\text { Decomposited } 17.2-100 \% \text { of DON by irradiation. } \\
\text { Decontaminated } 25.0-86.0 \% \text { and } 60.0-100 \% \text { of ZEN by } \\
\text { Y-rays and ultraviolet rays. } \\
\text { FB } 1 \text { was inactivated by } 63.5-100 \%, 58.1 \% \text { and } 93.3 \% \text { by } \\
\text { Y-rays, electron beam and microwave in feedstuffs. }\end{array}$ & {$[33-41]$} \\
\hline
\end{tabular}


Sorting and separation The mycotoxins are not uniformly distributed in grains, which mainly appeared in the moldy, broken and discolored parts [42, 43]. Meanwhile, the specific gravity of the mycotoxinscontaminated cereals is relatively lower than the normal ones. These characteristics enable sieving, aspiration, gravity separation, photoelectric separation, image processing techniques to be used to isolate the mycotoxinscontaminated feedstuffs [27, 44]. Specifically, Matumba et al. [27] reported that flotation, dehulling and hand sorting alone can remove at least $51 \%, 63 \%, 93 \%$ of aflatoxins (AFs), trichothecenes and fumonisins, respectively, from the shelled white maize, while $98 \%$ of these mycotoxins can be removed when combining three of these methods. However, these techniques are costly and only suitable for small-scale applications. Aspiration and gravity separation methods can reduce the DON in wheat, while it reduced the yield of harvested grain [21]. Additionally, near-infrared spectroscopy and optical visual sorting strategies can be used to detect the moldy maize and wheat kernels with more than $92 \%$ level of accuracy [22-28, 42-46].

Washing and solvent extraction According to the water-soluble or fat-soluble properties of mycotoxin, it could be decontaminated by washing with water or extraction with organic solvent [47]. Floating and washing with water can remove AFs, trichothecenes, ZEN and fumonisins by $51-72 \%, 64-69 \%, 2-61 \%$ and $73-74 \%$, respectively, from the grains [25, 27, 29]. Notably, floating and washing with a water solution consists of $10-30 \%$ $\mathrm{NaCl}, 30 \%$ sucrose, or $1 \mathrm{~mol} / \mathrm{L}$ sodium carbonate can increase the removal rate of fumonisins from the corn and wheat $[25,48]$. A combination of washing and hand sorting technologies together can reduce $84 \%$ of fumonisins [49]. The solvents, including methanol, ethanol, hexane, acetonitrile, isopropanol and aqueous acetone, are most commonly used for mycotoxin extraction. Previous studies showed that hexane-aqueous acetonewater (56\%:42\%:2\%) and dimethyl ether can eliminate over $98 \%$ of AFs in oil crops [50, 51]. However, these methods have major disadvantages as they result in loss of nutrients, and costly due to drying and toxic extracts disposal, which limit their large-scale application.

Heating Thermal treatment has been applied for the decontamination of mycotoxins in feed for many years. The efficiency of this method depends on the chemical structure and concentration of mycotoxins, temperature, duration, moisture content, $\mathrm{pH}$ and ionic concentration during the thermal treatment [52]. $\mathrm{AFB}_{1}, \mathrm{DON}, \mathrm{ZEN}$ and $\mathrm{FB}_{1}$ are heat-stable compounds with decomposition temperatures more than $237,175,220,150{ }^{\circ} \mathrm{C}$, respectively $[30,53,54]$, which makes it difficult to eliminate them by conventional thermal processing. Conventional hydrothermal treatment (cooking) with pressure $(0.10$ $\mathrm{MPa}$ ) at $160{ }^{\circ} \mathrm{C}$ for 20 min can decompose $\mathrm{AFB}_{1}$ by 78 $88 \%$ in rice [31], as well as pressure heating $(0.10 \mathrm{MPa})$ at $120{ }^{\circ} \mathrm{C}$ for $4 \mathrm{~h}$ can degrade $\mathrm{AFB}_{1}$ by $95 \%$ in moist peanut powder [55]. Yumbe-Guevara et al. [30] reported that $90 \%$ of DON or ZEN in barley powder can be destroyed at $220{ }^{\circ} \mathrm{C}$ for 11 or $85 \mathrm{~min}$. Frying chips at $190{ }^{\circ} \mathrm{C}$ for 15 min or drying rice from 150 to $200{ }^{\circ} \mathrm{C}$ for 40 min resulted in a loss of $67-70 \%$ of $\mathrm{FB}_{1}$, while cooking rice at $100{ }^{\circ} \mathrm{C}$ for $10 \mathrm{~min}$ reduced $80 \%$ of $\mathrm{FB}_{1}$ [32, 56]. Nevertheless, thermal treatments use an excessive amount of energy, also high temperature-induced Maillard reaction would reduce the nutritional values of feed ingredients. This led to a restriction in the application of heat treatments in the feed industry [33].

Irradiation Irradiation might be a feasible technology for removing mycotoxins from the feed on an industrial scale. It can be classified into ionizing ( $x$-rays, $\gamma$-rays and electron beam) and non-ionizing radiations (ultraviolet rays, infrared and microwave) $[57,58]$. The action of irradiation on feedstuffs can induce physical, chemical and biological effects, which reduce or eliminate the mycotoxins $[59,60]$. Specifically, $\mathrm{AFB}_{1}$ can be reduced by $43.0-87.8 \%, 65.7-71.5 \%, 22.0-100 \%, 90.7 \%$ by $\gamma$-rays, electron beam, ultraviolet rays and microwave, respectively, in different cereals [33-35]. DON can be decomposed by $37.0-82.4 \%, 17.2-56.3 \%, 83.4-100 \%$ by $\gamma$-rays, electron beam and ultraviolet rays, respectively, in feedstuffs [3639]. ZEN can be decontaminated by $25.0-86.0 \%$ and $60.0-100 \%$ by $\gamma$-rays and ultraviolet rays, respectively, in grains [34, 36-38]. $\mathrm{FB}_{1}$ was inactivated by $63.5-100 \%$, $58.1 \%$ and $93.3 \%$ by $\gamma$-rays, electron beam and microwave, respectively, in feedstuffs $[35,40,41]$. These different decomposition efficiencies of irradiation depend on the variation in the treatment condition, including doses and time of irradiation, the shape and composition of feedstuffs [61, 62]. Although irradiations can be considered as a potentially promising approach to decontaminate mycotoxins in feedstuffs, their safety issues such as mutagenesis that generates harmful microorganisms and damage the nutritional values of feedstuffs require a declaration and further studies.

Adsorption Adsorption binders can form a complex with mycotoxins, thus prevent mycotoxins passage from the gastrointestinal tract into the blood and organs of animals. In the past decades, numerous binders from different origins have been investigated for their capacity to adsorb mycotoxins $[52,63]$. Therefore, the adsorbent detoxification treatment is currently well understood and widely used to detoxify mycotoxins in the feed industry. In general, any ideal mycotoxin absorbent should 
possess these following properties, including high adsorption capacity against either range of mycotoxins (especially mycotoxins with low hydrophobicity), low non-specific binding to nutrients, as well as high safety, stability and palatability [52]. Table 2 shows lists of current patents related to adsorbing mycotoxin including $\mathrm{AFB}_{1}, \mathrm{DON}, \mathrm{ZEN}$ and $\mathrm{FB}_{1}$ control in the feed.

Aluminosilicate minerals, as the largest class of mycotoxin adsorbents, are the most widely applied and studied minerals in the decontamination of mycotoxin. Such adsorption binders mainly include bentonite, montmorillonite, zeolite, hydrated sodium calcium aluminosilicate, kaolin, illite, etc. [63]. The binding efficacy of mineral adsorbents is associated with the structures of both the binders and the mycotoxins. The binding efficiency depends significantly on the surface area, charge distribution and pore size of adsorption binders and the charge distribution, polarity and shape of the mycotoxins [52]. Some mycotoxins such as AFs have an ionic charge, thus clay minerals such as bentonite, illite, zeolite and kaolin are effective at removing them from the feed with more than $90 \%$ efficiency [87]. Numerous

Table 2 Summary of adsorbents with mycotoxins mitigation effects ${ }^{a}$

\begin{tabular}{|c|c|c|c|}
\hline Adsorbent & Mycotoxins & Binding efficiency & Reference \\
\hline Zeolite & $\mathrm{AFB}_{1}$ & $\begin{array}{l}\text { Decreased } A F B_{1} \text { residue in duck meat by } 65 \% \text { significantly and numerically } \\
\text { decreased } A F B_{1} \text { residue in liver and egg. }\end{array}$ & {$[64]$} \\
\hline Bentonite clay & $\mathrm{AFB}_{1}$ & Decreased liver $A F B_{1}$ residue by $41-87 \%$ when broilers fed $A F B_{1}$ in diet. & {$[65]$} \\
\hline Sodium bentonite & $\mathrm{AFB}_{1}$ & Decreased liver $A F B_{1}$ residue by $62.5 \%$ when broilers fed $A F B_{1}$ in diet. & {$[66]$} \\
\hline Modified maifanite & ZEN & $\begin{array}{l}\text { Decreased ZEN residue in liver and muscle by } 54.96 \% \text { and } 42.41 \% \\
\text { respectively at the dose of } 1 \% \text { when pig fed } 1.11 \mathrm{mg} / \mathrm{kg} \mathrm{AFB} \text { in diet. }\end{array}$ & {$[67]$} \\
\hline Bentonite or montmorillonite & $\mathrm{AFB}_{1}, \mathrm{ZEN}$ & $\begin{array}{l}\text { Decreased rumen concentration of } A F B_{1} \text { and } Z E N \text {, decreased } A F M_{1} \text { in milk } \\
\text { and } Z E N \text { in feces. }\end{array}$ & {$[68]$} \\
\hline Organo-clay composites & $\mathrm{AFB}_{1}$ & $\begin{array}{l}\text { Decreased } A F B_{1} \text { concentrations in liver, kidney and plasma significantly in } \\
\text { chickens. }\end{array}$ & {$[69]$} \\
\hline Tri-octahedral bentonite & DON, ZEN & $\begin{array}{l}\text { Adsorbed more than } 90 \% \text { of } Z E N \text { and } F_{1} \text { while the adsorption dose up to } \\
0.20 \%, w / v \text {. }\end{array}$ & {$[70]$} \\
\hline Pillared montmorillonite & DON & Adsorbed $14.7-23.4 \%$ and $21.8-27.4 \%$ of DON at at pH 2.0 and pH 6.8 . & {$[71]$} \\
\hline $\begin{array}{l}\text { Nonionic surfactant octylphenol } \\
\text { polyoxyethylene ether modified } \\
\text { montmorillonites }\end{array}$ & $\mathrm{AFB}_{1}, \mathrm{ZEN}$ & $\begin{array}{l}\text { The adsorption capacities of modified montmorillonites to } A F B_{1} \text { and ZEN } \\
\text { increased up to } 2.78 \text { and } 8.54 \mathrm{mg} / \mathrm{g} \text { respectively from } 0.51 \text { and } 0.00 \mathrm{mg} / \mathrm{g} \text { by } \\
\text { the raw montmorillonite. }\end{array}$ & {$[72]$} \\
\hline Hydrated sodium calcium alumino silicate & $\mathrm{AFB}_{1}, \mathrm{FB}_{1}$ & $\begin{array}{l}\text { Adsorbed } \mathrm{AFB}_{1} \text { and } \mathrm{FB}_{1} \text { in an aqueous solution, and the adsorption ratio } \\
\text { ranged from } 95.3 \% \text { to } 99.1 \% \text { and } 84.7 \% \text { to } 92.4 \% \text {, respectively. }\end{array}$ & {$[73]$} \\
\hline $\begin{array}{l}\text { Modified Hydrated sodium calcium } \\
\text { alumino silicate }\end{array}$ & DON & Reduced the toxicity of DON in weaning piglets. & {$[16]$} \\
\hline Esterified glucomannan & $\begin{array}{l}\text { AFs, ZEN, } \\
\text { DON }\end{array}$ & Adsorbed $95 \%, 80 \%$ and $12 \%$ of aflatoxin, ZEN and DON. & {$[73,74]$} \\
\hline $\begin{array}{l}\text { Inactivated yeast cell wall and low Yeast } \\
\text { fermenting volatile organic compound }\end{array}$ & AFs, DON & Decreased AFs and DON synthesis by $82 \%$ and $93 \%$ respectively. & {$[75]$} \\
\hline $\begin{array}{l}\text { Distillers' wet grain, distillers' dried grains } \\
\text { and distillers' dried grain with solubles }\end{array}$ & DON, ZEN & $\begin{array}{l}\text { Adsorbed } 48.9 \% \text { and } 67.9 \% \text { of DON and ZEN ( } 1 \mathrm{ppm} \text { each) using } 5 \mathrm{~g} / \mathrm{L} \text { of } \\
\text { micronized }(20 \mathrm{mkm}) \text { yeast mass at } 37^{\circ} \mathrm{C} \text { for } 1 \mathrm{~h} .\end{array}$ & {$[76]$} \\
\hline Yeast cell wall extract & ZEN & $\begin{array}{l}\text { Adsorbed } 40 \% \text { of the total ZEN content in the intestines in monogastric } \\
\text { animals. }\end{array}$ & {$[77,78]$} \\
\hline Activated charcoal & $\mathrm{AFB}_{1}, \mathrm{ZEN}$ & $\begin{array}{l}\text { Reduced the toxicity of } \mathrm{AFB}_{1} \text { on broilers and decreased the absorption rate } \\
\text { of ZEN in small intestine from } 32 \% \text { to } 5 \% \text { when adding } 2 \% \text {. }\end{array}$ & {$[79,80]$} \\
\hline Cholestyramine & ZEN & Decreased the absorption rate of ZEN in small intestine from $32 \%$ to $16 \%$. & {$[80]$} \\
\hline Magnetic carbon nanocomposites & $\mathrm{AFB}_{1}$ & Adsorbed nearly $90 \%$ of $\mathrm{AFB}_{1}$ within 180 min at $\mathrm{pH} 7.0$. & {$[81]$} \\
\hline Cross-lined chitosan polymers & $\begin{array}{l}\mathrm{AFB}_{1}, \mathrm{ZEN} \\
\mathrm{FB}_{1}, \mathrm{DON}\end{array}$ & $\begin{array}{l}\text { Adsorbed } 73 \% \mathrm{AFB}_{1}, 94 \% \mathrm{ZEN} \text { and } 99 \% \mathrm{FB}_{1} \text {, but the adsorption ratio of DON } \\
\text { less than } 30 \% \text {. }\end{array}$ & {$[82]$} \\
\hline Polyvinylpyrrolidone & ZEN & Adsorbed $2.1 \mathrm{mg} / \mathrm{g}$ of ZEN. & {$[83]$} \\
\hline Lactobacillus casei & $\mathrm{AFB}_{1}$ & Reduced the absorption of aflatoxin in the intestinal tract significantly. & {$[84]$} \\
\hline Lactobacillus plantarum F22 & $\mathrm{AFB}_{1}$ & Adsorbed $56.8 \%$ of $\mathrm{AFB}_{1}$. & {$[85]$} \\
\hline Lactobacillus plantarum B7 & $\mathrm{FB}_{1}$ & Adsorbed $52.9 \%$ of $\mathrm{FB}_{1}$. & {$[86]$} \\
\hline Lactobacillus pentosus X8 & $\mathrm{FB}_{1}$ & Adsorbed $58 \%$ of $\mathrm{FB}_{1}$. & {$[86]$} \\
\hline
\end{tabular}

${ }^{\mathrm{a}} A F s$ Aflatoxins, $A F B_{1}$ Aflatoxin $\mathrm{B}_{1}, \mathrm{DON}$ deoxynivalenol, $\mathrm{ZEN}$ : zearalenone; $\mathrm{FB}_{1}$ : fumonisin $\mathrm{B}_{1}$ 
studies reported that zeolite, bentonite clay and sodium bentonite decreased $\mathrm{AFB}_{1}$ residues in the liver by 41$87 \%$ and numerically decreased $\mathrm{AFB}_{1}$ residue in the meat and egg when broilers or ducks fed $\mathrm{AFB}_{1}$ contaminated diet [64-66]. Chen et al. [67] reported that ZEN residue in liver and muscle of pigs were decreased by $55.0 \%$ and $42.4 \%$, respectively, when supplemented with $1.0 \%$ modified maifanite in diet included $1.11 \mathrm{mg} / \mathrm{kg}$ ZEN. In ruminant feed, bentonite or montmorillonite decreased rumen concentration of $\mathrm{AFB}_{1}$ and $\mathrm{ZEN}$ and also decreased $\mathrm{AFM}_{1}$ in the milk and ZEN in the feces in goats [68]. Tzou et al. [69] prepared organo-clay composites by mixing bentonite-enriched clay with nonionic surfactants (Brij 30 and Igepal CO-890) and added organo-clay composites to feed. After chickens had consumed amended feed for 11 weeks, $\mathrm{AFB}_{1}$ concentrations in the liver, kidney, and plasma were significantly lower than the $\mathrm{AFB}_{1}$ control dietary treatment. Although many aluminosilicate adsorbents can adsorb strongly polar toxins, such as $\mathrm{AFB}_{1}, \mathrm{FB}_{1}$, etc. as supported by many studies, they appear to be ineffective at absorbing other non-aflatoxin mycotoxins including DON and ZEN [88, 89]. Bentonites have been considered as promising adsorbents for high-efficient removal of mycotoxins from the animal feed as they are eco-friendly, low-cost and highly efficient in adsorption of mycotoxins, modifying clays also could help to increase their adsorptive ability to non-polar mycotoxins [90-92]. To date, only one dioctahedral bentonite $(1 \mathrm{~m} 588)$ was authorized as an antiaflatoxin additive by the EU Regulation in 2009 [93]. Vila-Donat et al. [70] reported that tri-octahedral bentonite could adsorb more than $90 \%$ of $\mathrm{ZEN}$ and $\mathrm{FB}_{1}$ while the adsorption dose up to $0.20 \%(\mathrm{w} / \mathrm{v})$. Nonionic surfactant octylphenol polyoxyethylene ether and modified montmorillonites, as mycotoxins adsorbent, were used for adsorption of $\mathrm{AFB}_{1}$ and weak polar $\mathrm{ZEN}$ in both single and binary-contaminate systems by simulating the conditions of the gastrointestinal tract. Modified montmorillonites increased the adsorption capacities to $\mathrm{AFB}_{1}$ from $0.51 \mathrm{mg} / \mathrm{g}$ of raw montmorillonite to 2.78 $\mathrm{mg} / \mathrm{g}$ and ZEN from $0.00 \mathrm{mg} / \mathrm{g}$ of raw montmorillonite to $8.54 \mathrm{mg} / \mathrm{g}$ [72]. Adsorption of DON by pillared montmorillonite modified with aluminum, iron and titanium was investigated using UPLC-MSMS (at $\mathrm{pH} 2.0$ and 6.8) and the results demonstrated that the adsorption ratios were $14.7-23.4 \%$ at $\mathrm{pH} 2.0$ and $21.8-27.4 \%$ at $\mathrm{pH} 6.8$ [71]. The commercially hydrated sodium calcium aluminosilicate has an excellent capability of adsorbing $\mathrm{AFB}_{1}$ and $\mathrm{FB}_{1}$ in an aqueous solution, and the adsorption ratio ranged from $95.3-99.1 \%$ and $84.7-92.4 \%$ of the available $\mathrm{AFB}_{1}$ and $\mathrm{FB}_{1}$, respectively [73]. Mineral adsorbents have been modified with quaternary long-chain alkyl/aryl amines to improve the adsorption of nonaflatoxin mycotoxins [74]. The binder Amdetox $^{\text {Tm }}$ is mainly comprised of hydrated sodium calcium aluminosilicate that has been modified by cetylpyridinium chloride and intercalation with $\beta$-glucan [94]; these modifications increase the surface area of hydrated sodium calcium aluminosilicate, which maximizes the binding of mycotoxins with minimal adsorption of nutrients. Zhang et al. [16] reported that a modified hydrated sodium calcium aluminosilicate adsorbent could reduce the toxicity of DON in weaning piglets [16]. Furthermore, it must be noted that these adsorbents can adsorb micronutrients and have negative effects on the bioavailability of trace minerals and vitamins.

Second generation adsorbents have been developed originating from the cell wall component of microorganisms. Glucomannan is a common adsorbent that cannot be used by gut microbes and strongly adsorbed toxic substances and harmful pathogenic bacteria in animals. Mycotoxins can be adsorbed by esterified glucomannan, which is a kind of broad-spectrum mycotoxin adsorbent with an effective binding ability for AFs, ZEN, FBs and DON by $95 \%, 75 \%, 59 \%$ and $12 \%$, respectively [73, 74]. Esterified glucomannan has been proved to improve the adverse consequences of mycotoxins on the performance, immunity, blood haematological and biochemical indices of chickens $[70,76,78,94]$. The $\beta$ - $D$-glucan chains of yeast cell walls have been demonstrated to effectively inactivate ZEN [77, 95]. Zeidan et al. [75] reported that inactivated yeast cell walls and low yeast fermenting (L. thermotolerans) volatile organic compounds could decrease AFs and DON synthesis by $82 \%$ and $93 \%$, respectively, in vitro. A combination of mineral clay and yeast cell walls showed a considerably enhanced binding capacity of AFs, ZEN and fumonisins in an in vitro study; however, the adsorption abilities toward DON, ochratoxin A and T-2 toxin were low $(<60 \%)$ [96]. The yeast biomass obtained from distillers' wet grain, distillers' dried grains and distillers' dried grain with solubles have the ability to bind various mycotoxins and adsorbed $48.9 \%$ and $67.9 \%$ of DON and ZEN (1.0 $\mathrm{mg} / \mathrm{kg}$ each), respectively, using $5.0 \mathrm{~g} / \mathrm{L}$ micronized yeast mass at $37{ }^{\circ} \mathrm{C}$ for $1 \mathrm{~h}$ [76]. In addition, the yeast cell walls extract adsorbed ZEN in the gastrointestinal tracts of monogastrics [77] and was able to adsorb $40 \%$ of the total ZEN contents in the intestines [78].

Activated charcoal, as a general adsorbent, has a large surface area and excellent adsorption capabilities in aqueous environments. Activated charcoal has demonstrated the ability to reduce AFs, ZEN, DON due to its porous structure in several studies [97, 98]. The partial protection induced by activated charcoal in lowering mycotoxin residues in the liver of broilers has been observed previously $[65,99]$. The addition of $0.1 \%$ activated carbon to feed containing $10 \mathrm{mg} / \mathrm{kg} \mathrm{AFB}{ }_{1}$ was able to reduce the detrimental effects of $\mathrm{AFB}_{1}$ on broilers [79]. 
Avantaggiato et al. [80] found that the absorption rate of ZEN in the small intestine decreased from 32\% to $5 \%$ when activated carbon was added at $2.0 \%$ in an in vitro gastrointestinal model. Cholestyramine is an anion exchange resin. The addition of cholestyramine decreased the absorption rate of ZEN in the small intestine from $32 \%$ to $16 \%$ using a laboratory model that mimics the metabolic processes of the gastrointestinal tract of healthy pigs [80]. Polyvinylpyrrolidone has good adsorption and selectivity. In vitro adsorption experiments showed that polyvinylpyrrolidone could adsorb $0.3 \mathrm{mg} / \mathrm{g}$ of ZEN, and the adsorption capacity of modified polyvinylpyrrolidone could be increased to adsorb $2.1 \mathrm{mg} / \mathrm{g}$ of ZEN [83]. Durian peel is an agricultural waste that is widely used for organic and inorganic pollutant adsorption. Adunphatcharaphon et al. [100] reported that the acidtreated durian peel adsorbed $98.4 \%$ of $\mathrm{AFB}_{1}, 98.4 \%$ of ZEN, $86.1 \%$ of $\mathrm{FB}_{1}$ and $2.0 \%$ of DON through its larger surface area and a surface charge modification.

Numerous studies have suggested that removal of mycotoxins with magnetic materials is effective and these are promising adsorbents in the feed industry. Magro et al. [101] reported that the adsorbent-mycotoxin complex was characterized and was structurally and magnetically well conserved [101]. Magnetic carbon nanocomposites produced by maize wastes were used for the removal of $\mathrm{AFB}_{1}$, and the adsorption ratio was nearly $90 \%$ within $180 \mathrm{~min}$ at $\mathrm{pH} 7.0$ [81]. In addition, cross-linked chitosan polymers as generic adsorbents for simultaneous adsorption could adsorb multiple mycotoxins. Cross-linked chitosan-glutaraldehyde complex presented high adsorption capability for $\mathrm{AFB}_{1}$ (73\%), ZEN (94\%) and $\mathrm{FB}_{1}$ (99\%), but no obvious adsorption for DON and T-2 toxin $(<30 \%)$ [82]. Some volatile bioactive compounds have proved to be effective in inhibiting mould growth and reducing mycotoxin accumulation.

The principle of microbial adsorbent detoxification is that the bacterium adsorbs mycotoxins to form a complex and then excretes it together with the toxins, thus reducing the hazard [102]. Lactic acid bacteria and yeast are the most studied microbial adsorbents. Lactobacillus casei can significantly reduce the absorption of aflatoxin in the intestinal tract [84]. Zeng et al. [85] reported that Lactobacillus plantarum F22 had a strong adsorption capacity on $\mathrm{AFB}_{1}$ and the adsorption rate could reach $56.8 \%$. Lactobacillus plantarum B7 and Lactobacillus pentosus X8 can remove $52.9 \%$ and $58.0 \%$ of $\mathrm{FB}_{1}$ [86]. Halttunen et al. [103] compared the adsorption effect of multiple lactic acid bacteria on aflatoxin and they found that a composite agent consisting of multiple lactic acid bacteria was more effective than a single strain.

\section{Chemical methods}

Chemical techniques can destroy the structure of the mycotoxins, which generate mildly toxic or nontoxic products. Decontamination of mycotoxin by chemical techniques primarily includes alkaline and ozone treatments, as well as other chemical agent treatments [104, 105]. The commonly used methods of chemical detoxification of mycotoxins are summarized in Table 3.

Alkaline treatment Alkaline chemicals, including ammonia, sodium hydroxide, potassium hydroxide and sodium carbonate, etc., have been used for the destruction of various mycotoxins in the moldy feedstuffs $[104,105]$. The lactone ring structure of $\mathrm{AFB}_{1}$ can be opened by base hydrolysis to produce coumarin sodium salt and then further be eliminated by washing with water [120]. Ammoniation and hydroxide salts treatments are the common approach that has been used to remove $\mathrm{AFB}_{1}$ from feed ingredients, with more than $95 \%$ removal rate in various cereals [107-110]. An epoxide at C-12 and C13, essential for the toxicity of DON, can be destructed under alkaline conditions [28]. Sodium carbonate and hydroxide salts treatments can reduce DON by 83.9$100 \%$ in different feedstuffs $[111,112]$. Although these treatments could nearly reduce the complete concentration of mycotoxins, the possible transformation of mycotoxins to other forms such as masked mycotoxins, along with the harmful side effects on the environment and food (changes in nutritional quality, texture, or flavor), the quality and safety assessments of chemically treated products are necessary $[104,105]$.

Ozone treatment Mycotoxin oxidizing agent treatment is an effective detoxification method through changing the molecular structure of mycotoxins. The oxidizers commonly used are ozone, hydrogen peroxide, sodium and calcium hypochlorite, chlorine and other oxidizers [106, 121]. AFs, DON, ZEN and $\mathrm{FB}_{1}$ have been shown to be effectively degraded by ozone [122-124]. Agriopoulou et al. [125] has found that ozone has the ability to degrade $\mathrm{AFs}\left(\mathrm{AFB}_{1}, \mathrm{AFB}_{2}, \mathrm{AFG}_{1}\right.$ and $\left.\mathrm{AFG}_{2}\right)$. Trombete et al. [126] reported that ozone concentration, form and exposure time influenced positively the reduction of DON, AFs and fungal count. AFs can be reduced by $92-$ $95 \%$ in corn and by $91 \%$ or $78 \%$ in cottonseed or peanut meal, respectively, by ozone $[113,127,128]$. DON can be reduced by $70-90 \%$ in corn and by $20-80 \%$ in wheat by ozone [112, 114-116]. The degradation of ZEN in corn can reach $90.7 \%$ through the ozone treatment with $100 \mathrm{mg} / \mathrm{L}$ ozone for $180 \mathrm{~min}$ [117]. Furthermore, there are other oxidizing agents such as sodium hypochlorite and hydrogen peroxide that can effectively degrade mycotoxins $[118,119,129,130]$. 
Table 3 Summary of physical methods for mycotoxins detoxification ${ }^{a}$

\begin{tabular}{|c|c|c|c|}
\hline Methods & Measures and reagents & Detoxification efficiency & Reference \\
\hline \multirow[t]{2}{*}{$\begin{array}{l}\text { Alkaline } \\
\text { treatment }\end{array}$} & $\begin{array}{l}\text { Ammonia, sodium hydroxide, potassium hydroxide } \\
\text { and sodium carbonate etc. }\end{array}$ & $\begin{array}{l}\text { Removed } 95 \% \text { of } \mathrm{AFB}_{1} \text { in various cereals by ammoniation and } \\
\text { hydroxide salts treatments. }\end{array}$ & {$[106-111]$} \\
\hline & & $\begin{array}{l}\text { Reduced DON by } 83.9-100 \% \text { in different feedstuffs through sodium } \\
\text { carbonate and hydroxide salts treatments. }\end{array}$ & \\
\hline $\begin{array}{l}\text { Ozone } \\
\text { treatment }\end{array}$ & $\begin{array}{l}\text { Ozone, hydrogen peroxide, chlorine, sodium and } \\
\text { calcium hypochlorite etc. }\end{array}$ & $\begin{array}{l}\text { Reduced } 92-95 \%, 91 \% \text { and } 78 \% \text { of AFBs in corn, cottonseed and pea- } \\
\text { nut meal respectively by ozone. } \\
\text { DON can be reduced } 70-90 \% \text { in corn and } 20-80 \% \text { in wheat by ozone. } \\
\text { The degradation of ZEN in corn can reach } 90.7 \% \text { through the ozone } \\
\text { treatment with } 100 \mathrm{mg} / \mathrm{L} \text { ozone for } 180 \mathrm{~min} \text {. }\end{array}$ & [112-119] \\
\hline
\end{tabular}

${ }^{\mathrm{a}} A F B_{1}$ Aflatoxin $\mathrm{B}_{1}, D O N$ deoxynivalenol, $Z E N$ zearalenone, $F B_{1}$ fumonisin $\mathrm{B}_{1}$

Although the ozone treatment can result in a complete reduction in the mycotoxin concentration, it can cause changes in the physical and chemical composition of the feed, such as changes in starch structure, lipid oxidation, protein denaturation, color change and processing properties $[106,113,126]$. Moreover, these treatments may produce some harmful chemicals to the health of animals $[106,113,126]$.

\section{Biological methods}

Although many physical and chemical decontamination strategies have been developed to reduce or eliminate mycotoxins in feed ingredients or complete feed, few techniques met the requirements of practical application owing to their limitation of binding efficiency, bio-safety or cost-effectiveness. Therefore, as a promising strategy, biodegradation of mycotoxin by microorganism or enzymes attracted the attention of scientists [131-133]. The biological strategies that have been developed for the biodegradation of $\mathrm{AFB}_{1}, \mathrm{DON}, \mathrm{ZEN}$ and $\mathrm{FB}_{1}$ in the feed are presented in Table 4.

Microorganisms with detoxification activities Biology-based detoxification methods are widely recognized as specific, efficient and environment-friendly. The nutritive and sensory characteristics like color and flavor are reserved without involving harmful chemicals. Screening and isolating naturally existing microorganisms that show biotransformation capabilities against specific mycotoxins have been a popular strategy. Mycotoxin biodegradation technology is the process by which the toxic group of the mycotoxin molecules is broken down and destroyed by the secondary metabolites produced by microorganisms or their secreted intracellular and extracellular enzymes, while producing non-toxic or less toxic degradation products.

A number of different fungal have been shown to detoxify $\mathrm{AFB}_{1}$. Fungal strains such as $S$. cerevisiae ŁOCK 0119 has been shown to degrade $\mathrm{AFB}_{1}$ at levels of $69.0 \%$ [131]. Similarly, some studies reported that the ability of various Aspergillus strains such as $A$. niger FS10 and $A$. niger RAF106 have shown the ability to degrade $\mathrm{AFB}_{1}$ to levels between $88.6 \%$ and $98.7 \%$ [132, 133]. Bacteria degraded AFs mainly by secreting extracellular enzymes. Some strains of Nocardia corynebacterioides, Flavobacterium aurantiacum and Bacillus have been shown to degrade $\mathrm{AFB}_{1}$. Smiley and Draughon reported that the degradation efficiency of $\mathrm{AFB}_{1}$ by Nocardia corynebacterioides reached $74.5 \%$ in $24 \mathrm{~h}$ [159]. Flavobacterium aurantiacum could degrade $\mathrm{AFB}_{1}$ efficiently and its crude protein extract could degrade $74.5 \%$ of $\mathrm{AFB}_{1}[160$, 161]. Bacillus is an important class of bacteria capable of degrading $\mathrm{AFB}_{1}$. Farzaneh et al. [141] isolated Bacillus subtilis UTBSP1 from Iranian pistachio nut and the degradation rate of $\mathrm{AFB}_{1}$ reached 78.4-95.0\%. Bacillus subtilis ANSB060 isolated from the fish intestine could degrade $81.5 \%$ of $\mathrm{AFB}_{1}$ within $72 \mathrm{~h}$ [162]. In addition, other Bacillus such as Bacillus licheniformis CFR1, Bacillus velezensis DY3108, Bacillus subtilis JSW-1 and Bacillus shackletonii $\mathrm{L} 7$ have been able to degrade $\mathrm{AFB}_{1}$ to levels between 67.2-94.7\% [136-139]. Other bacteria such as Pseudomonas putida, Escherichia coli CG1061 and Stenotrophomonas sp. CW117 also showed very efficient biodegradation rates up to $90 \%$ or more for $\mathrm{AFB}_{1}$ [134, 135, 140].

Devosia insulae A16, Strain E3-39, Bacterial consortium C20, Pseudomonas sp. Y1 and Lysobacter sp. S1 isolated from soil samples can convert DON to 3-ketoDON or 3-epi-DON, a less toxic derivative [142, 144, $145,150]$. Several studies have revealed that these strains resulted in $74-100 \%$ reduction of DON [142, 144, 145, 150]. From a different point of view, Bacterial isolates LS100 and SS3, Bacterial strain BBSH 797 and Eggerthella sp. DII-9 presented a high biotransformation activity of converting DON to diepoxy-deoxynivalenol $[146,148,149]$. Strains isolated from the intestine of donkeys and soil samples, namely Bacillus subtilis ASAG 216 and Aspergillus (NJA-1) have shown to decrease DON concentration by $81.1 \%$ and $94.4 \%[143,147]$.

Microorganisms metabolize ZEN mainly through conversion or degradation to $\alpha$-zearalenol, $\beta$-zearalenol, sulfate and other secondary metabolites with low or 
Table 4 Biological biotransformation approaches by microorganisms for the detoxification of mycotoxins ${ }^{a}$.

\begin{tabular}{|c|c|c|c|}
\hline Mycotoxins & Microorganisms & Biotransformation efficiency & Reference \\
\hline \multirow[t]{11}{*}{$\overline{A F B}$} & Aspergillus niger FS10 & $98.65 \%$ & [133] \\
\hline & Aspergillus niger RAF106 & $88.59 \%$ & [132] \\
\hline & Stenotrophomonas sp. CW117 & $100.00 \%$ & [134] \\
\hline & S. cerevisiae ŁOCK 0119 & $69.00 \%$ & [131] \\
\hline & Escherichia coli CG1061 & $93.70 \%$ & [135] \\
\hline & Bacillus velezensis DY3108 & $91.50 \%$ & [136] \\
\hline & Bacillus subtilis JSW-1 & $67.20 \%$ & [137] \\
\hline & Bacillus shackletonii $\mathrm{L} 7$ & $92.10 \%$ & [138] \\
\hline & Bacillus licheniformis CFR1 & $94.70 \%$ & [139] \\
\hline & Pseudomonas putida & $90.00 \%$ & {$[140]$} \\
\hline & Bacillus subtilis UTBSP1 & $95.00 \%$ & [141] \\
\hline \multirow[t]{9}{*}{ DON } & Bacterial consortium C20 & $74.29 \%$ & {$[142]$} \\
\hline & Bacillus subtilis ASAG 216 & $81.10 \%$ & [143] \\
\hline & Devosia insulae A16 & $88.00 \%$ & [144] \\
\hline & Pseudomonas sp. Y1 and Lysobacter sp. S1 & $100.00 \%$ & [145] \\
\hline & Eggerthella sp. DII-9 & $100.00 \%$ & {$[146]$} \\
\hline & Aspergillus (NJA-1) & $94.40 \%$ & {$[147]$} \\
\hline & Bacterial isolates LS100 \& SS3 & $100.00 \%$ & [148] \\
\hline & Bacterial strain BBSH 797 & - & [149] \\
\hline & Strain E3-39 & $100.00 \%$ & {$[150]$} \\
\hline \multirow[t]{5}{*}{ ZEN } & Bacillus subtilis & $100.00 \%$ & [151] \\
\hline & Bacillus natto & $87.00 \%$ & [151] \\
\hline & Bacillus pumilus ES-21 & $95.70 \%$ & [152] \\
\hline & Bacillus amyloliquefaciens ZDS-1 & $95.70 \%$ & [153] \\
\hline & Bacillus subtilis ANSB01G & $88.65 \%$ & [154] \\
\hline \multirow[t]{4}{*}{$\mathrm{FB}_{1}$} & Bacterial consortium SAAS79 & $100.00 \%$ & {$[155]$} \\
\hline & Strain NCB 1492 & $100.00 \%$ & {$[156]$} \\
\hline & Saccharomyces cerevisiae IS1/1 and SC82 & $22 \%-50 \%$ & {$[157]$} \\
\hline & Bacillus spp. S9, S10 and S69 & $43 \%-83 \%$ & {$[158]$} \\
\hline
\end{tabular}

${ }^{a} A F B_{1}$ Aflatoxin $B_{1}, D O N$ deoxynivalenol, $Z E N$ zearalenone, $F B_{1}$ fumonisin $B_{1}$ -means the biotransformation efficiency did not reported

non-toxicity. Bacillus natto and Bacillus subtilis strains were shown to remove ZEN from the liquid medium: more than $75 \%$ ZEN could be biodegraded after incubation. In another study, up to $99 \%$ of ZEN was degraded by $B$. subtilis strain [151]. Lei et al. [154] isolated Bacillus subtilis ANSB01G from broiler intestinal chyme, and the degradation rate of ZEN by this strain in a liquid medium, natural mold corn, distillers' dried grain with solubles and a complete pig feed were $88.7 \%, 84.6 \%, 66.3 \%$ and $83.0 \%$, respectively. Bacillus pumilus ES-21 and Bacillus amyloliquefaciens ZDS-1, isolated from soil samples, showed 95.7\% reduction of ZEN [152, 153].

Some fungal and bacterial microorganisms have been reported to be able to degrade fumonisins. Styriak et al.
[157] screened two strains of preserved yeast from the laboratory that were able to significantly degrade fumonisins in the culture medium. One is Saccharomyces cerevisiae IS1/1, which can degrade $45 \%$ of $\mathrm{FB}_{1}$ and $50 \%$ of the mixture $\mathrm{FB}_{1}$ and $\mathrm{FB}_{2}$ in the culture medium, the other one is Saccharomyces cerevisiae SC82, which also degrade $\mathrm{FB}_{1}$ and the mixture $\mathrm{FB}_{1}$ and $\mathrm{FB}_{2}$, the degradation rates were $22 \%$ and $25 \%$, respectively [157]. Camilo et al. [158] screened three strains such as Bacillus spp. S9, S10 and S69, that degraded $43 \%, 48 \%$ and $83 \% \mathrm{FB}_{1}$, respectively. Strain NCB 1492, isolated from soil samples, can completely degrade $\mathrm{FB}_{1}$ under $25^{\circ} \mathrm{C}$, after $24 \mathrm{~h}$ [156]. Notably, another study reported that the degradation rate of $\mathrm{FB}_{1}$ by Bacterial consortium SAAS79 can reach $100 \%$ [155]. 
The usage of catabolizing enzymes Although some microorganisms are highly active in biodegrading mycotoxins, some of them might secrete harmful metabolites or cannot survive in the gastrointestinal tract of the animals $[163,164]$. Therefore, screening the enzymes from these microorganisms might be the promising strategy to solve the issues. Recently, there are many researches that have focused on the isolation of the enzymes that can biodegrade $\mathrm{AFB}_{1}, \mathrm{DON}, \mathrm{ZEN}$ and $\mathrm{FB}_{1}$. The enzymes for the biodegradation of $\mathrm{AFB}_{1}, \mathrm{DON}, \mathrm{ZEN}$ and $\mathrm{FB}_{1}$ in the feed are presented in Table 5.

The main fungal enzymes known to have degradation activity against $\mathrm{AFB}_{1}$ are laccase and oxidase [163]. The enzyme for $\mathrm{AFB}_{1}$ detoxification designated as aflatoxindetoxifizyme was reported [164]. The gene was identified and cloned from an Armillariella tabescens. The recombinant aflatoxin-detoxifizyme was able to detoxify $\mathrm{AFB}_{1}$ and significantly reduce its mutagenic effects. Manganese peroxidase $(1.5 \mathrm{U} / \mathrm{mL})$ can degrade $90 \% \mathrm{AFB}_{1}$ after $48 \mathrm{~h}$ of reaction [165]. Alberts et al. [167] recombinantly expressed the laccase gene by gene cloning and its degradation rate of $\mathrm{AFB}_{1}$ was $55 \%$. Bacillus aflatoxindegrading enzyme and myxobacteria aflatoxin degradation enzyme secreted by Bacillus shackletonii L7 and Myxococcus fulvus ANSM068 are also efficient in degrading $\mathrm{AFB}_{1}[138,166]$.

Although there are early reports on an NADHdependent bacterial cytochrome P450 system that transforms DON into 16-hydroxy-DON, no efficient DON biotransformation enzymes are patented yet [172]. Peroxidase such as manganese peroxidase and lignin peroxidase showed the potential for significant DON degradation $[168,171]$. Aldo-keto reductase DepA and
DepB can transfer DON to 3-keto-DON and 3-epi-DON which have lower toxicity than DON [170]. A quinonedependent dehydrogenase and two NADPH-dependent aldo/keto reductases (AKR13B2 and AKR6D1) can detoxify deoxynivalenol in wheat via epimerization in a Devosia strain [169].

Laccases are copper-containing oxidases have high potential in degrading the heat-stable mycotoxin ZEN, which involved in many industrial application $[176,177]$. A novel ZEN-specific lactonohydrolase was developed previously as a producer of different hydrolytic enzymes for feed biorefinery. The recombinant ZEN-specific lactonohydrolase secreted by the transformed fungal clones into the culture liquid was shown to remove ZEN [173]. A recombinant fusion enzyme by combining two single genes named ZEN-specific lactonohydrolase and carboxypeptidase have demonstrated that can completely degrade ZEN to the non-toxic product in $2 \mathrm{~h}$ at an optimum $\mathrm{pH}$ of 7 and a temperature of $35^{\circ} \mathrm{C}$ [174].

The fumonisin carboxylesterase FumD can degrade $\mathrm{FB}_{1}$ to its less toxic metabolite the hydrolyzed $\mathrm{FB}_{1}$ in the gastrointestinal tract of turkeys and pigs [175]. Within 2 $\mathrm{h}$ of incubation with FumD, $\mathrm{FB}_{1}$ was completely degraded to hydrolyzed $\mathrm{FB}_{1}$ in the duodenum and jejunum in an ex vivo pig model [175].

\section{Nutritional strategies}

It is well accepted that none of the physical, chemical or biological strategies can totally decontaminate the mycotoxin in feed, considering that even a low consumption level of a mycotoxin can cause chronic toxicity including a reduction of the performance and immunosuppression in animals [45], therefore, development of nutritional

Table 5 The usage of degrading enzymes for the detoxification of mycotoxins ${ }^{a}$

\begin{tabular}{|c|c|c|c|}
\hline Mycotoxins & Degrading enzyme & Origin & Reference \\
\hline \multirow[t]{5}{*}{$\overline{\mathrm{AFB}_{1}}$} & Bacillus aflatoxin-degrading enzyme & Bacillus shackletonii L7 & [138] \\
\hline & Manganese peroxidase & Pleurotus ostreatus & [165] \\
\hline & Aflatoxin-Oxidase & Armillariella tabescens & [163] \\
\hline & Myxobacteria aflatoxin degradation enzyme & Myxococcus fulvus ANSM068 & [166] \\
\hline & Laccase & White rot fungi & {$[167]$} \\
\hline \multirow[t]{5}{*}{ DON } & Manganese peroxidase and Lignin peroxidase & Spent Mushroom Substrate & {$[168]$} \\
\hline & $\begin{array}{l}\text { Quinone-dependent dehydrogenase, NADPH-dependent aldo/ } \\
\text { keto reductases }\end{array}$ & Devosia sp. D6-9 & [169] \\
\hline & Aldo-keto reductase DepA/DepB & Devosia mutans 17-2-E-8 & {$[170]$} \\
\hline & Peroxidase & Rice bran & {$[171]$} \\
\hline & Cytochrome P450 system & Sphingomonas sp. strain KSM1 & {$[172]$} \\
\hline \multirow[t]{2}{*}{ ZEN } & ZEN-specific lactonohydrolase & Recombinant enzymes & [173] \\
\hline & $\begin{array}{l}\text { A fusion enzyme by combining ZEN-specific lactonohydrolase } \\
\text { and carboxypeptidase }\end{array}$ & $\begin{array}{l}\text { Clonostachys rosea strain IFO7063 and Bacillus } \\
\text { amyloliquefaciens strain ASAG1 }\end{array}$ & {$[174]$} \\
\hline $\mathrm{FB}_{1}$ & Fumonisin carboxylesterase FumD & Recombinant enzymes & {$[175]$} \\
\hline
\end{tabular}

${ }^{\mathrm{a}} A F B_{1}$ Aflatoxin $B_{1}, D O N$ deoxynivalenol, ZEN zearalenone, $F B_{1}$ fumonisin $B_{1}$ 
strategies to help mitigation of the mycotoxicoses is also important. Some nutritional strategies that have been disclosed are presented in Table 6.

It is feasible to modulate the mycotoxin detoxification system through nutritional measures. On the one hand, detoxification systems in animals including CYP450s, ketoreductase, $\alpha$-glutathione transferase, etc. can degrade mycotoxins $[9,10]$. Therefore, any nutrient that can promote the normal functioning of one of the above detoxification enzyme systems can be used as a nutritional regulator. Glutamate, cysteine and glycine can be used as substrates for the synthesis of glutathione and participate in the detoxification process by forming glutathione. On the other hand, mycotoxins can reduce nutrient uptake, so adding critical nutrients is one of the ways to mitigate the harmful effects of mycotoxins [13-15].

Oxidative stress is an important mechanism of cytotoxicity caused by mycotoxins $[9,10]$. Adding antioxidants to mycotoxin-contaminated feed can improve the antioxidant capacity of the organism and increase the resistance of livestock and poultry to mycotoxins. Selenium, some vitamins A, C and E, and their precursors have marked antioxidant properties that act as superoxide anion scavengers. For these reasons, these substances have been investigated as protecting agents against toxic effects of mycotoxins. Selenium is an essential trace element for humans and animals as it plays an important role in antioxidant defense, anticancer, immunity, and detoxification [181, 182]. Previous studies have shown that dietary selenium supplementation can help to protect against $\mathrm{AFB}_{1}$-induced hepatotoxicity, immunotoxicity, and genotoxicity in chicks, which is mainly associated with regulation of redox/inflammation/apoptotic signaling and CYP450 isozymes [11]. Selenium has the potential to counteract DON-induced immunosuppression in piglets by increased the expression levels of IL-2, IL-10, IFN- $\gamma$, IgG, and IgM mRNA and protein in piglet splenic lymphocyte [190]. Selenium, vitamins C and $\mathrm{E}$ could be used as antioxidants to protect the spleen and brain cell membranes from DON toxicity and against DNA damage in liver caused by DON [191]. Nagaraj et al. [183] reported that dietary supplemented vitamin $B_{1}$ reduced the toxicity of fusarium in chicks. Vitamin E supplementation counteracts the adverse impacts of $\mathrm{FB}_{1}$ on reproductive hormones, gestation length and milk production in rabbits [196]. Grosse et al. [195] observed that retinol, as-corbic acid and alpha-tocopherol reduced DNA adducts in the kidney and liver of mice exposed to ochratoxin A and ZEN from 70-90\%. Carotenoids (carotene and xanthophylls) are excellent antioxidants with antimutagenic and anticarcinogenic properties, which have been demonstrated can inhibit $\mathrm{AFB}_{1}$-induced liver DNA damage in rats [178].

Silymarin is a potent antihepatotoxic agent provide protection against the negative effects of $\mathrm{AFB}_{1}$ on performance of broiler chicks [184]. Curcumin alleviates $\mathrm{AFB}_{1}$ toxicity through downregulating CYP450 enzymes, promoting ATPase activities in chickens [185]. Pretreatment with silymarin, curcumin enhanced the viability of cells exposed to the mycotoxins and attenuated reactive oxygen species formation by DON, partially reduced ROS formation by $\mathrm{FB}_{1}[180]$. Curcumin significantly decreased apoptosis in cells exposed to DON, whereas silymarin was able to prevent apoptosis exposed to $\mathrm{FB}_{1}$ and DON in PK-15 cells [180]. Gao et al. [17] reported that dietary silymarin supplementation protected rats from ZEN-induced hepatotoxicity and reproductive toxicity through improvement in the antioxidant capacity and regulation in the genes related to ZEN metabolism, hormone synthesis, protein synthesis, and $\mathrm{ABC}$ transporters in the tissues.

Butylated hydroxytoluene, a dietary antioxidant in mammals, has been shown to lessen the toxic effects of $\mathrm{AFB}_{1}$ by inducing the activity of glutathione sulfotransferase and inhibiting the activity of cytochrome P450 1A5 [198]. Li et al. [186] reported that alpha lipoic acid improved the growth performance and alleviated the

Table 6 Nutritional strategies to mitigate mycotoxins toxicity ${ }^{a}$

\begin{tabular}{|c|c|c|c|}
\hline Mycotoxins & Nutritional strategies & Mechanisms & Reference \\
\hline $\mathrm{AFB}_{1}$ & $\begin{array}{l}\text { Selenium, vitamins } C_{\text {, vitamins }} \text {, vitamin } B_{1} \text {, carotenoids, } \\
\text { silymarin, curcumin, butylated hydroxytoluene, alpha lipoic } \\
\text { acid, quercetin, resveratrol, rhamnoides oil }\end{array}$ & $\begin{array}{l}\text { Mainly by improving antioxidant capacity and } \\
\text { detoxification enzyme activities to alleviate the harm of } \\
\mathrm{AFB}_{1} \text { to livestock and poultry }\end{array}$ & $\begin{array}{l}{[11,178-} \\
188]\end{array}$ \\
\hline DON & $\begin{array}{l}\text { Selenium, vitamins C, vitamins E, silymarin, curcumin, } \\
\text { functional amino acid (methionine, glutamic acid, arginine, } \\
\text { aspartate and lysine), antimicrobial peptide, astragalus }\end{array}$ & $\begin{array}{l}\text { Primarily through enhancement of antioxidant capacity } \\
\text { and immune functions to improve the resistance to DON } \\
\text { in livestock and poultry. }\end{array}$ & $\begin{array}{l}{[179,180} \\
189-194]\end{array}$ \\
\hline ZEN & $\begin{array}{l}\text { Retinol, as-corbic acid, alpha-tocopherol, silymarin, soybean } \\
\text { isoflavone }\end{array}$ & $\begin{array}{l}\text { Alleviated the toxic effects of ZEN by improving the } \\
\text { antioxidant capacity and inhibiting the estrogenic toxicity } \\
\text { of ZEN. }\end{array}$ & $\begin{array}{l}{[17,190,} \\
195]\end{array}$ \\
\hline $\mathrm{FB}_{1}$ & Vitamin E, silymarin, curcumin, soybean isoflavone & $\begin{array}{l}\text { Mainly via counteracting the oxidative stress caused by } \\
\mathrm{FB}_{1} \text { to livestock. }\end{array}$ & $\begin{array}{l}{[180,196,} \\
197]\end{array}$ \\
\hline
\end{tabular}

${ }^{\mathrm{a}} A F B_{1}$ Aflatoxin $\mathrm{B}_{1}, D O N$ deoxynivalenol, $Z E N$ zearalenone, $F B_{1}$ fumonisin $B_{1}$ 
liver damage associated with improved the antioxidant capacity in the broilers exposed to $\mathrm{AFB}_{1}$. Quercetin exerted its beneficial effects by depressing the bioactivation of $\mathrm{AFB}_{1}$ and counterbalancing its pro-oxidant effects in a bovine mammary epithelial cell line [187]. Resveratrol, a polyphenol derived from red grapes, berries and peanuts, exerted anti-inflammatory and antioxidant effects. Dietary supplementation of resveratrol helped in increasing the activities of the oxidative enzymes and in improving the plasma total antioxidant capacity and total protein in broilers fed with $\mathrm{AFB}_{1}$ [188]. Solcan et al. [199] reported that rhamnoides oil had a potent hepatoprotective activity, reduced the concentration of AFs in the liver and diminished their adverse effects in broilers.

Andretta et al. [192] suggested that methionine can alleviate the DON induced adverse effects in growing pigs. Supplementing glutamic acid, arginine, aspartate and lysine to a diet had positive effects on remission of visceral disease induced by DON, enhancement of antioxidant ability and improvement of blood physiological and biochemical indexes of fattening pigs [200]. Dietary supplementation of $2.0 \%$ glutamic acid could mitigate DON induced negative effects on the growth performance and intestinal injury in the weaned piglets [193]. Xiao et al. $[179,194]$ found that an antimicrobial peptide complex composed of lactoferrin peptide, plant defensin and active yeast effectively improved the adverse effects of DON on production performance, autoimmunity and intestinal functions of weaned piglets. Astragalus played an important role in the reduction of immunosuppression and organ damages of the liver and kidney induced by DON and can improve the immunofunction significantly in mice [189]. Wang et al. [190] suggested that soybean isoflavone added to diets at $600 \mathrm{mg} / \mathrm{kg}$ could reduce the harmful effects induced by $2.0 \mathrm{mg} /$ $\mathrm{kg}$ ZEN on the reproductive organs in prepubertal gilts during the growth phase. In an in vivo study on rats, Lu [197] reported that soybean isoflavone extract has a marked protective action against $\mathrm{FB}_{1}$ hepatotoxicity by the suppression of $\mathrm{FB}_{1}$-stimulated prostaglandin production.

\section{Conclusion and perspectives}

The occurrence of mycotoxins in the feed is of a great concern and an unavoidable problem in the feed industry around the world. Mycotoxins also endanger human health through the cycle of the food chain. This review summarizes a number of strategies to reduce mycotoxin contamination in terms of physical detoxification (separation, washing, heating, irradiation and adsorption), chemical treatments (bases and oxidizing agents), biological detoxification methods (microorganisms and enzymes), and nutritional regulation strategies. Each of these approaches can be practically used while along with their own advantages and disadvantages. However, with the growing awareness of environmental protection as well as feed and food safety, there is a growing expectation for more green and innovative technologies to control mycotoxin contamination.

\section{Abbreviations \\ AFs: Aflatoxins; $\mathrm{AFB}_{1}$ : Aflatoxin $\mathrm{B}_{1}$; DON: Deoxynivalenol; ZEN: Zearalenone; $\mathrm{FB}_{1}$ : Fumonisin $\mathrm{B}_{1}$}

\section{Acknowledgments}

We apologize in advance to the investigators, whose studies were inadequately presented or their studies related to this review but were not described in this manuscript.

\section{Authors' contributions}

LHS conceptualized and designed this review. ML, LZ, GXG, LZ, LS, JFD, YMH, and YYW collected the data. ML and LHS wrote the manuscript. MMK and JFD have revised the grammar of the manuscript. All authors have read and approved the final manuscript.

\section{Funding}

This project was supported by the Chinese Natural Science Foundation projects (32072775 and 31772636), and Nutreco N.V. (Netherlands).

\section{Availability of data and materials}

The datasets used and/or analyzed during the current study are publicly available.

\section{Declarations}

Ethics approval and consent to participate

Not applicable.

\section{Consent for publication}

All authors have approved the final manuscript.

\section{Competing interests}

The authors declare no conflict of interest.

\section{Author details}

${ }^{1}$ Hubei Hongshan Laboratory, College of Animal Science and Technology, Huazhong Agricultural University, Wuhan 430070, Hubei, China. ${ }^{2}$ Department of Agriculture of Sichuan Province, Chengdu 610041, China. ${ }^{3}$ Trouw Nutrition, Amersfoort, The Netherlands. ${ }^{4}$ Animal Production Department, Faculty of Agriculture, Benha University, Banha 13736, Egypt.

Received: 2 August 2021 Accepted: 29 November 2021

Published online: 28 January 2022

\section{References}

1. Steyn PS. Mycotoxins, general view, chemistry and structure. Toxicol Lett. 1995:82-83:843-51.

2. Haque MA, Wang Y, Shen Z, Li X, Saleemi MK, He C. Mycotoxin contamination and control strategy in human, domestic animal and poultry: A review. Microb Pathog. 2020;142:104095.

3. Sun LH, Lei MY, Zhang NY, Zhao L, Krumm CS, Qi DS. Hepatotoxic effects of mycotoxin combinations in mice. Food Chem Toxicol. 2014;74:289-93.

4. Ma R, Zhang L, Liu M, Su YT, Xie WM, Zhang NY, et al. Individual and combined occurrence of mycotoxins in feed ingredients and complete feeds in china. Toxins (Basel). 2018;10(3):113.

5. Zhao L, Zhang L, Xu ZJ, Liu XD, Chen LY, Dai JF, et al. Occurrence of Aflatoxin B1, deoxynivalenol and zearalenone in feeds in China during 2018-2020. J Anim Sci Biotechnol. 2021;12:74.

6. Lee HJ, Ryu D. Worldwide occurrence of mycotoxins in cereals and cerealderived food products: public health perspectives of their co-occurrence. J Agric Food Chem. 2017;65(33):7034-51.

7. Zhang LY, Zhao XJ, Liu S, Zhang YG. Biological detoxification of aflatoxin for food and feed: a review. Chin J Anim Nutr. 2019;31(2):521-9. 
8. International Agency for Research on Cancer (IARC). IARC Monographs on the evaluation of carcinogenic risk of chemicals to humans-overall evaluation of carcinogenicity: an updating of IARC monographs. IARC Lyon France. 1987;7(1):106-16.

9. Sun LH, Zhang NY, Zhu MK, Zhao L, Zhou JC, Qi DS. Prevention of aflatoxin $B_{1}$ hepatoxicity by dietary selenium is associated with inhibition of cytochrome P450 isozymes and up-regulation of 6 selenoprotein genes in chick liver. J Nutr. 2016;146(4):655-61.

10. Zhang NY, Qi M, Zhao L, Zhu MK, Guo J, Liu J, et al. Curcumin prevents aflatoxin $B_{1}$ hepatoxicity by inhibition of cytochrome P450 isozymes in chick liver. Toxins (Basel). 2016:8(11):327.

11. Zhao L, Feng Y, Deng J, Zhang NY, Zhang WP, Liu XL, et al. Selenium deficiency aggravates aflatoxin $B_{1}$-induced immunotoxicity in chick spleen by regulating 6 selenoprotein genes and redox/inflammation/apoptotic signaling. J Nutr. 2019;149(6):894-901.

12. Kócsó DJ, Ali O, Kovács M, Mézes M, Balogh K, Kachlek ML, et al. A preliminary study on changes in heat shock protein 70 levels induced by Fusarium mycotoxins in rats: in vivo stud. Mycotoxin Res. 2021;37(2):141-8.

13. Ji X, Zhang Q, Zheng WJ, Yao W. Morphological and molecular response of small intestine to lactulose and hydrogen-rich water in female piglets fed Fusarium mycotoxins contaminated diet. J Anim Sci Biotechnol. 2019;10:9.

14. Shi D, Zhou J, Zhao L, Rong X, Fan Y, Hamid H, et al. Alleviation of mycotoxin biodegradation agent on zearalenone and deoxynivalenol toxicosis in immature gilts. J Anim Sci Biotechnol. 2018;9:42.

15. Liu M, Zhang L, Chu XH, Ma R, Wang YW, Liu Q, et al. Effects of deoxynivalenol on the porcine growth performance and intestina microbiota and potential remediation by a modified HSCAS binder. Food Chem Toxicol. 2020;141:111373.

16. Zhang L, Ma R, Zhu MX, Zhang NY, Liu XL, Wang YW, et al. Effect of deoxynivalenol on the porcine acquired immune response and potential remediation by a novel modified HSCAS adsorbent. Food Chem Toxicol. 2020;138:111187.

17. Gao X, Xiao ZH, Liu M, Zhang NY, Khalil MM, Gu CQ, et al. Dietary silymarin supplementation alleviates zearalenone-induced hepatotoxicity and reproductive toxicity in rats. J Nutr. 2018;148(8):1209-16.

18. Takemura H, Shim JY, Sayama K, Tsubura A, Zhu BT, Shimoi K. Characterization of the estrogenic activities of zearalenone and zeranol in vivo and in vitro. J Steroid Biochem Mol Biol. 2007;103(2):170-7.

19. Gao X, Sun LH, Zhang NY, Li C, Zhang J, Xiao ZH, et al. Gestational zearalenone exposure causes reproductive and developmental toxicity in pregnant rats and female offspring. Toxins (Basel). 2017;9(1):21.

20. Chen J, Wei Z, Wang $Y$, Long M, Wu WD, Kuca K. Fumonisin $B_{1}$ : mechanisms of toxicity and biological detoxification progress in animals. Food Chem Toxicol. 2021;149(3):111977.

21. Salgado JD, Wallhead M, Madden LV, Paul PA. Grain harvesting strategies to minimize grain quality losses due to fusarium head blight in wheat. Plant Dis. 2011;95(11):1448-57.

22. Cui GJ. Research on photoelectric sorting technology of wheat grain with red mold. Henan Univ Technol. 2013.

23. Liu Y, Yamdeu JH, Gong YY, Orfila C. A review of postharvest approaches to reduce fungal and mycotoxin contamination of foods. Compr Rev Food Sci Food Saf. 2020;19(4):1521-60.

24. Hu D, Wu A. Chemical and physical treatments for reducing mycotoxin contaminations. In: Wu A, editors. Food Safety \& Mycotoxins. Singapore: Springer; 2019. p. 145-62.

25. Karlovsky P, Suman M, Berthiller F, De Meester J, Eisenbrand G, Perrin I, et al. Impact of food processing and detoxification treatments on mycotoxin contamination. Mycotoxin Res. 2016;32(4):179-205.

26. Shi HT, Li SL, Bai YY, Prates LL, Lei YG, Yu PQ. Mycotoxin contamination of food and feed in China: Occurrence, detection techniques, toxicological effects and advances in mitigation technologies. Food Control. 2018:91:202-15.

27. Matumba L, Poucke CV, Ediage EN, Jacobs B, Saeger SD. Effectiveness of hand sorting, flotation/washing, dehulling and combinations thereof on the decontamination of mycotoxin-contaminated white maize. Food Addit Contam Part A Chem Anal Control Expo Risk Assess. 2015;32(6): 960-9.

28. Shapira R, Paster N. Control of mycotoxins in storage and techniques for their decontamination. Mycotoxins Food Detect Control. 2004:190-223.
29. Fandohan P, Zoumenou D, Hounhouigan DJ, Marasas WFO, Wingfield MJ, Hell K. Fate of aflatoxins and fumonisins during the processing of maize into food products in Benin. Int J Food Microbiol. 2005;98(3):249-59.

30. Yumbe-Guevara BE, Imoto T, Yoshizawa T. Effects of heating procedures on deoxynivalenol, nivalenol and zearalenone levels in naturally contaminated barley and wheat. Food Addit Contam. 2003;20(12):1132-40.

31. Park JW, Kim YB. Effect of pressure cooking on aflatoxin $B_{1}$ in rice. J Agric Food Chem. 2006:54(6):2431-5.

32. Becker-Algeri TA, Heidtmann-Bemvenuti R, Hackbart HCS, Badiale-Furlong E. Thermal treatments and their effects on the fumonisin $B_{1}$ level in rice. Food Control. 2013;34(2):488-93.

33. Pankaj SK, Shi H, Keenera KM. A review of novel physical and chemical decontamination technologies for aflatoxin in food. Trends Food Sci Tech. 2018;71:73-83.

34. Aziz NH, Moussa LAA, Far FM. Reduction of fungi and mycotoxins formation in seeds by gamma-radiation. J Food Safety. 2004;24(2):109-27.

35. Yang J. Research on irradiation-induced degradation of mycotoxins in agricultural products [D]. Chin Acad Agric Sci. 2009.

36. Hooshmand $\mathrm{H}$, Klopfenstein CF. Effects of gamma irradiation on mycotoxin disappearance and amino acid contents of corn, wheat, and soybeans with different moisture contents. Plant Foods Hum Nutr. 1995:47(3):227-38.

37. Aziz NH, Attia ES, Farag SA. Effect of gamma-irradiation on the natural occurrence of Fusarium mycotoxins in wheat, flour and bread. Nahrung. 1997:41(1):34-7.

38. Murata $H$, Mitsumatsu M, Shimada N. Reduction of feed-contaminating mycotoxins by ultraviolet irradiation: an in vitro study. Food Addit Contam Part A Chem Anal Control Expo Risk Assess. 2008;25(9):1107-10.

39. Zhang K. Study on the degradation effect of electron beam irradiation on deoxynivalenol of Fusarium oxysporum in wheat with red mold. Henan Univ Technol. 2014.

40. Aziz NH, El-Far FM, Shahin AA, Roushy SM. Control of Fusarium moulds and fumonisin $B_{1}$ in seeds by gamma-irradiation. Food Control. 2007;18(11): 1337-42.

41. Xiao LX, Wang F, Yu HT, Zhao XY, Hu XS. Detoxication of aflatoxin $B_{1}$ and fumonisin $B_{1}$ in purple corn. Food Sci. 2011;32(9):114-7.

42. Mutungi C, Muthoni F, Bekunda M, Gaspar A, Kabula E, Abass A. Physical quality of maize grain harvested and stored by smallholder farmers in the Northern Highlands of Tanzania : Effects of harvesting and pre-storage handling practices in two marginally contrasting agro-locations. J Stored Prod Res. 2019;84:101517.

43. Reddy KR, Reddy CS, Abbas HK, Abel CA, Muralidharan K. Mycotoxigenic fungi, mycotoxins, and management of rice grains. Toxin Rev. 2008;27:287317.

44. Tibola CS, Fernandes MC, Guarienti EM. Effect of cleaning, sorting and milling processes in wheat mycotoxin content. Food Control. 2016;60:174-9.

45. Delwiche SR, Pearson TC, Brabec DL. High-speed optical sorting of soft wheat for reduction of deoxynivalenol. Plant Dis. 2005;89(11):1214-9.

46. Chu X, Tao Y, Wang W, Yuan Y, Xi MJ. Rapid detection method of moldy maize kernels based on color feature. Adv Mech Eng. 2014;6:625090.

47. Braunberg RC, Gantt OO, Friedman L. Toxicological evaluation of compounds found in food using rat renal explants. Food Chem Toxicol. 1982;20(5):541-6.

48. Shetty PH, Bhat RV. A physical method for segregation of fumonisincontaminated maize. Food Chem. 1999;66:371-4.

49. Westhuizen L, Shephard GS, Rheeder JP, Burger HM, Gelderblom WC, Wild $C P$, et al. Optimising sorting and washing of home-grown maize to reduce fumonisin contamination under laboratory-controlled conditions. Food Control. 2011:22:396-400.

50. Wang CY. Measures to deal with aflatoxin in food. China New Technol New Prod. 2010;171(5):8.

51. Cui CP. Study on cultivation of Rhodococcus erythropolis and its degradation of aflatoxinB ${ }_{1}$. Ocean Univ China. 2012.

52. Kabak B, Dobson A, Var I. Strategies to prevent mycotoxin contamination of food and animal feed: a review. Crit Rev Food Sci Nutr. 2006:46(8):593-619.

53. Jackson LS, Hlywka JJ, Senthil KR, Bullerman LB, Musser SM. Effects of time, temperature, and $\mathrm{pH}$ on the stability of fumonisin $\mathrm{B}_{1}$ in an aqueous model system. J Agric Food Chem. 1996;44(3):906-12.

54. Ryu D, Hanna AM, Eskridge MK, Bullerman BL. Heat stability of zearalenone in an aqueous buffered model system. J Agric Food Chem. 2003;51 (6):1746-8.

55. Fan HY. Integrated control of aflatoxin in feed. Hebei Anim Husb Vet. 2003; 019(001):40-1. 
56. Jackson LS, Katta SK, Fingerhut DD, DeVries JW, Bullerman LB. Effects of baking and frying on the fumonisin $B_{1}$ content of corn-based foods. J Agric Food Chem. 1997;45(12):4800-5.

57. Aziz NH, Moussa LA. Influence of gamma-radiation on mycotoxin producing moulds and mycotoxins in fruits. Food Control. 2002;13(4-5):281-8.

58. Molins RA, Motarjemi Y. K"aferstein F K. Irradiation: a critical control point in ensuring the microbiological safety of raw foods. Food Control. 2001;12(6): 347-56.

59. He JW, Zhou T. Patented techniques for detoxification of mycotoxins in feeds and food matrices. Recent Pat Food Nutr Agric. 2010;2(2):96-104.

60. Scott PM. Industrial and farm detoxification processes for mycotoxins. Rev Med Vet Fr. 1998;146(6):543-8.

61. Jubeen F, Bhatti IA, Khan MZ, Hassan ZU, Shahid M. Effect of UVC irradiation on aflatoxins in ground nut (arachis hypogea) and tree nuts (juglans regia, prunus duclus and pistachio vera). J Chem Soc Pakistan. 2012;34(6):1366-74.

62. Suzuki T. Light-irradiation wavelength and intensity changes influence aflatoxin synthesis in fungi. Toxins (Basel). 2018;10(1):31.

63. Adamovic' M, Stojanovic' M, Grubišic' M, Ileš D, Milojkovic' J. Importance of aluminosilicate minerals in safe food production. Macedonian Journal of Animal Science. 2011;1:175-80.

64. Sumantri I, Herliani H, Yuliani M, Nuryono N. Effects of zeolite in aflatoxin $B_{1}$ contaminated diet on aflatoxin residues and liver histopathology of laying duck. Conf Ser Earth Environ Sci. 2018;207:012017.

65. Bhatti SA, Khan MZ, Hassan ZU, Saleemi MK, Saqib M, Khatoon A, et al. Comparative efficacy of Bentonite clay, activated charcoal and trichosporon mycotoxinivorans in regulating the feed-to-tissue transfer of mycotoxins. J Sci Food Agric. 2017;98(3):884-90.

66. Magnoli AP, Texeira M, Rosa CA, Miazzo RD, Cavaglieri LR, Magnoli CE, et al. Sodium bentonite and monensin under chronic aflatoxicosis in broiler chickens. Poult Sci. 2011;90(2):352-7.

67. Chen Q, Lu Z, Hou W, Shi B, Shan A. Effects of modified maifanite on zearalenone toxicity in female weaner pigs. Ital J Anim Sci. 2015;14(2):3597.

68. Gouda GA, Khattab HM, Abdel-Wahhab MA, El-Nor SA, El-Sayed HM, Kholif SM. Clay minerals as sorbents for mycotoxins in lactating goat's diets: intake, digestibility, blood chemistry, ruminal fermentation, milk yield and composition, and milk aflatoxin M1 content. Small Rumin Res. 2019;175(6): $15-22$.

69. Tzou YM, Chan YT, Chen SE, Wang CC, Chiang PN, Teah HY, et al. Use 3-D tomography to reveal structural modification of bentonite-enriched clay by nonionic surfactants: Application of organo-clay composites to detoxify aflatoxin $B_{1}$ in chickens. J Hazard Mater. 2019;375(5):312-9.

70. Vila-Donat P, Marín S, Sanchis V, Ramos AJ. Tri-octahedral bentonites as potential technological feed additive for fusarium mycotoxin reduction. Food Addit Contam Part A Chem Anal Control Expo Risk Assess. 2020;37(8): 1374-87.

71. Zhang Q, Zhang YL, Liu SS, Wu YZ, Zhou Q, Zhang YZ, et al. Adsorption of deoxynivalenol by pillared montmorillonite. Food Chem. 2020;343(1):128391.

72. Wang G, Lian C, Xi YF, Sun ZM, Zheng SL. Evaluation of nonionic surfactant modified montmorillonite as mycotoxins adsorbent for aflatoxin $B_{1}$ and zearalenone. J Colloid Interface Sci. 2018;518:48-56.

73. Aly SE, Abdel-Galil MM, Abdel-Wahhab MA. Application of adsorbent agents technology in the removal of aflatoxin $B_{1}$ and fumonisin $B_{1}$ from malt extract. Food Chem Toxicol. 2004;42(11):1825-31.

74. Daković A, Tomašević-Čanović M, Rottinghaus GE, Matijašević S, Sekulić Z. Fumonisin $B_{1}$ adsorption to octadecyldimethylbenzyl ammonium-modified clinoptilolite-rich zeolitic tuff. Microporous Mesoporous Mater. 2007;105: 285-90.

75. Zeidan R, Ul-Hassan Z, Al-Thani R, Balmas V, Jaoua S. Application of lowfermenting yeast Lachancea thermotolerans for the control of toxigenic fungi Aspergillus parasiticus, Penicillium verrucosum and Fusarium graminearum and their mycotoxins. Toxins (Basel). 2018;10(6):242.

76. Tranquil DT, Tranquil E. Compositions and methods for mycotoxin decontamination, nucleotide, protein and vitamin enrichment and palatability enhancement of food and animal feed using micronized yeast biomass. US Patent Appl Publ. 2012; No. 20120082759 A1

77. Yiannikouris A, André G, Buléon A, Jeminet G, Canet I, François J, et al. Comprehensive conformational study of key interactions involved in zearalenone complexation with beta-D-glucans. Biomacromolecules. 2004; 5(6):2176-85.

78. Yiannikouris A, Kettunen H, Apajalahti J, Pennala E, Moran CA. Comparison of the sequestering properties of yeast cell wall extract and hydrated sodium calcium aluminosilicate in three in vitro models accounting for the animal physiological bioavailability of zearalenone. Food Addit Contam Part A Chem Anal Control Expo Risk Assess. 2013;30(9):1641-50.

79. Dalvi RR, Mcgowan C. Experimental induction of chronic aflatoxicosis in chickens by purified aflatoxin B1 and its reversal by activated charcoal, phenobarbital, and reduced glutathione. Poult Sci. 1984;63(3):485-91.

80. Avantaggiato G, Havenaar R, Visconti A. Assessing the zearalenone-binding activity of adsorbent materials during passage through a dynamic in vitro gastrointestinal model. Food Chem Toxicol. 2003;41(10):1283-90.

81. Khan F, Zahoor M. In vivo detoxification of aflatoxin $B_{1}$ by magnetic carbon nanostructures prepared from bagasse. BMC Vet Res. 2014;10:255.

82. Zhao ZY, Liu N, Yang LC, Wang JH, Song SQ, Nie DX, et al. Cross-linked chitosan polymers as generic adsorbents for simultaneous adsorption of multiple mycotoxins. Food Cont. 2015;57:362-9.

83. Ramos AJ, Hernández E. In vitro aflatoxin adsorption by means of a montmorillonite silicate. A study of adsorption isotherms. Anim Feed Sci Tech. 1996;62(2-4):263-9.

84. Hernandez-Mendoza A, Guzman-De-Peña D, González-Córdova AF, VallejoCórdoba B, Garcia HS. In vivo assessment of the potential protective effect of Lactobacillus casei Shirota against aflatoxin B. Dairy Sci Technol. 2010; 90(6):729-40.

85. Zeng D, Tang YR, Ni XQ, Zhang ZL, Ran J. Absorption characteristics of lactobacillus plantarum F22 to aflatoxin B . Food Sci. 2009;30:23.

86. Wang $X$, Zheng JY, Peng XL, Qiao YF, Zhou LL, Zhang BL. Study on the removal of fumonisins by Lactobacillus strains. Sci Technol Food Ind. 2015; 101(4):849-56.

87. Hart F. The use of naturally occurring minerals in animal feed. Ind Miner. 2014:565:22.

88. Kubena LF, Harvey RB, Huff WE, Elissalde MH, Yersin AG, Phillips TD, et al. Efficacy of a hydrated sodium calcium aluminosilicate to reduce the toxicity of aflatoxin and diacetoxyscirpenol. Poult Sci. 1993;72(1):51-9.

89. Mussaddeq Y, Begum I, Akhter S. Activity of aflatoxins adsorbents in poultry feed. Pak J Biol Sci. 2000;3(10):1697-9.

90. Phillips TD, Wang M, Elmore SE, Hearon S, Wang JS. NovaSil clay for the protection of humans and animals from aflatoxins and other contaminants. Clays Clay Miner. 2019;67(1):99-110.

91. Robinson A, Johnson NM, Strey A, Taylor JF, Marroquin-Cardona A, Mitchell $\mathrm{NJ}$, et al. Calcium montmorillonite clay reduces urinary biomarkers of FB 1 exposure in rats and humans. Food Addit Contam Part A Chem Anal Control Expo Risk Assess. 2012;29(5):809-18.

92. Li Y, Tian GY, Dong GY, Bai SS, Han XY, Liang JS, et al. Research progress on the raw and modified montmorillonites as adsorbents for mycotoxins: a review. Appl Clay Sci. 2018;163:299-311.

93. European Commission. Commission Regulation (EC) No 1060/2013 of 29 October 2013 concerning the authorisation of bentonite as feed additive for all animal species. 2013;289:33-7.

94. Wei JT, Wu KT, Sun H, Khalil MM, Dai JF, Liu Y, et al. A novel modified hydrated sodium calcium aluminosilicate (HSCAS) adsorbent can effectively reduce $\mathrm{T}-2$ toxin-induced toxicity in growth performance, nutrient digestibility, serum biochemistry, and small intestinal morphology in chicks. Toxins (Basel). 2019;11(4):199.

95. Yiannikouris A, Kwiatkowski S, Kudupoje MB, Matney C. Synthetic mycotoxin adsorbents and methods of making and utilizing the same. US Patent Publ. 2014:RE45274.

96. Howes AD, Newman KE. Compositions and methods for removal of mycotoxins from animal feed. US Patent Publ. 1999; No.6045834 A.

97. Alexander H, Stefan F, Othmar K, Hans D. Mycotoxin detoxication of animal feed by different adsorbents. Toxicol Lett. 2001;122(2):179-88.

98. Liu YL, Meng GQ, Wang HR, Zhu HL, Hou YQ, Wang WJ, et al. Effect of three mycotoxin adsorbents on growth performance: Nutrient retention and meat quality in broilers fed on mould-contaminated feed. Br Poult Sci. 2011; 52(2):255-63.

99. Teleb HM, Hegazy AA, Hussein YA. Efficiency of kaolin and activated charcoal to reduce the toxicity of low level of aflatoxins in broilers. Sci J King Faisal Univ. 2004,5:145-60.

100. Adunphatcharaphon S, Petchkongkaew A, Greco D, D'Ascanio D, Visessanguan W, Avantaggiato $G$. The effectiveness of durian peel as a multi-mycotoxin adsorbent. Toxins (Basel). 2020;12(2):108.

101. Magro M, Moritz DE, Bonaiuto E, Baratella D, Terzo M, Jakubec $P$, et al. Citrinin mycotoxin recognition and removal by naked magnetic nanoparticles. Food Chem. 2016;203:505-12 
102. LuoY LX, Yuan L, Li J. Complicated interactions between bio-adsorbents and mycotoxins during mycotoxin adsorption: Current research and future prospects. Trends Food Sci Tech. 2020;96:127-34.

103. Halttunen T, Collado MC, El-Nezami H, Meriluoto J, Salminen S. Combining strains of lactic acid bacteria may reduce their toxin and heavy metal removal efficiency from aqueous solution. Lett Appl Microbiol. 2008;46(2): $160-5$.

104. Jalili M, Son S. The effect of chemical treatment on reduction of aflatoxins and ochratoxin A in black and white pepper during washing. Food Addit Contam Part A Chem Anal Control Expo Risk Assess. 2011;28(4):485-93.

105. Dvorák M. Possibilities of chemical detoxification of aflatoxin. Vet Med (Praha). 1990;35(1):37-42.

106. McKenzie KS, Sarr AB, Mayura K, Bailey RH, Miller DR, Rogers TD, et al. Oxidative degradation and detoxification using a novel source of ozone. Food Chem Toxicol. 1997;35(8):807-20.

107. Masri MS, Vix HLE, Goldblatt LA. Process for de-toxifying substances contaminated with aflatoxin. US Patent. 1969: US3429709DA.

108. Gardner HK, Koltun SP, Dollear FG, Rayner ET. Inactivation of aflatoxins in peanut and cottonseed meals by ammoniation. J Am Oil Chem Soc. 1971 48(2):70-3.

109. Brekke OL, Stringfellow AC, Peplinski AJ. Aflatoxin inactivation in corn by aqua ammonia: laboratory trials. J Agric Food Chem. 1978;26(6):1383-9.

110. Park DL. Perspectives on mycotoxin decontamination procedures. Food Addit Contam. 1993;10(1):49-60.

111. Bretz M, Beyer M, Cramer B, Knecht A, Humpf HU. Thermal degradation of the Fusarium mycotoxin deoxynivalenol. J Agric Food Chem. 2006;54(17): 6445-51.

112. Young JC, Subryan LM, Potts D, McLaren ME. Reduction in levels of deoxynivalenol in contaminated corn by chemical and physical treatment. J. Agric Food Chem. 1986;34(3):465-7.

113. Prudente AD, King JM. Efficacy and safety evaluation of ozonation to degrade aflatoxin in corn. J Food Sci. 2002;67(8):2866-72.

114. Li R, Wang X, Zhou T, Yang D, Wang Q, Zhou Y. Occurrence of four mycotoxins in cereal and oil products in yangtze delta region of china and their food safety risks. Food Control. 2014;35(1):117-22.

115. Sun C, Ji J, Wu SL, Sun CP, Pi FW, Zhang YZ, et al. Saturated aqueous ozone degradation of deoxynivalenol and its application in contaminated grains. Food Control. 2016;69:185-90.

116. Wang L, Luo YP, Luo XH, Wang R, Li YF, Shao HL, et al. Effect of deoxynivalenol detoxification by ozone treatment in wheat grains. Food Control. 2016;66:137-44.

117. Qi LJ, Li YL, Luo XH, Wang R, Zheng RH, Wang L, et al. Detoxification of zearalenone and ochratoxin A by ozone and quality evaluation of ozonised corn. Food Addit Contam Part A Chem Anal Control Expo Risk Assess. 2016: 33(11):1700-10.

118. Trager W, Stoloff L. Possible reactions for aflatoxin detoxification. J Agric Food Chem. 1967;15(4):679-81.

119. Natarajan KR, Rhee KC, Cater CM, Mattil KF. Destruction of aflatoxins in peanut protein isolates by sodium hypochlorite. J Am Oil Chem Soc. 1975; 52(5):160-3.

120. Javanmardi F, Khodaei D, Sheidaei Z, Bashiry M, Nayebzadeh K, Vasseghian $Y$, et al. Decontamination of aflatoxins in edible oils: a comprehensive review. Food Rev Int. 2020;17:1-17.

121. Natarajan KR. Chemical inactivation of aflatoxins in peanut protein ingredients. J Environ Pathol Toxicol Oncol. 1992;11(4):217-27.

122. Alencar ER, Faroni LR, Soares NF, Silva WA, Carvalho MC. Efficacy of ozone as a fungicidal and detoxifying agent of aflatoxins in peanuts. J Sci Food Agric. 2012;92(4):899-905.

123. Piemontese L, Messia MC, Marconi E, Falasca L, Zivoli R, Gambacorta L, et al. Effect of gaseous ozone treatments on DON, microbial contaminants and technological parameters of wheat and semolina. Food Addit Contam Part A Chem Anal Control Expo Risk Assess. 2018;35(4):760-71.

124. Santos Alexandre AP, Vela-Paredes RS, Santos AS, Costa NS, CanniattiBrazaca SG, Calori-Domingues MA, et al. Ozone treatment to reduce deoxynivalenol (DON) and zearalenone (ZEN) contamination in wheat bran and its impact on nutritional quality. Food Addit Contam Part A Chem Anal Control Expo Risk Assess. 2018;35(6):1189-99.

125. Agriopoulou S, Koliadima A, Karaiskakis G, Kapolos J. Kinetic study of aflatoxins' degradation in the presence of ozone. Food Control. 2016;61: 221-6.
126. Trombete FM, Porto YD, Freitas-silva O, Pereira RV, Direito GM, Saldanha T, et al. Efficacy of ozone treatment on mycotoxins and fungal reduction in artificially contaminated soft wheat grains. J Food Process Pres. 2016;41(3): e12927.1-10.

127. Dwarakanath CT, Rayner ET, Mann GE, Dollear FG. Reduction of aflatoxin levels in cottonseed and peanut meals by ozonization. J Am Oil Chem Soc. 1968;45(2):93-5

128. McKenzie KS, Kubena LF, Denvir AJ, Rogers TD, Hitchens GD, Bailey RH, et al. Aflatoxicosis in turkey poults is prevented by treatment of naturally contaminated corn with ozone generated by electrolysis. Poult Sci. 1998; 77(8):1094-102.

129. Altug $T$, Yousef $A E$, Marth EH. Degradation of aflatoxin $B_{1}$ in dried figs by sodium bisulfite with or without heat, ultraviolet energy or hydrogen peroxide. J Food Prot. 1990;53(7):581-2.

130. Abd-Alla ES. Zearalenone: incidence, toxigenic fungi and chemical decontamination in Egyptian cereals. Nahrung. 1997;41(6):362-5.

131. Chlebicz A, Śliżewska K. In vitro detoxification of aflatoxin $B_{1}$, deoxynivalenol, fumonisins, T-2 Toxin and zearalenone by probiotic bacteria from genus lactobacillus and saccharomyces cerevisiae yeast. Probiotics Antimicrob Proteins. 2020;12(1):289-301.

132. Fang QA, Du MR, Chen JW, Liu T, Zheng Y, Liao ZL, et al. Degradation and detoxification of aflatoxin $B_{1}$ by tea-derived aspergillus niger RAF106. Toxins (Basel). 2020;12(12):777.

133. Qiu TY, Wang HM, Yang Y, Yu J, Ji J, Sun JD, et al. Exploration of biodegradation mechanism by $\mathrm{AFB}_{1}$-degrading strain Aspergillus niger FS10 and its metabolic feedback. Food Control. 2021;121(2):107609.

134. Cai MY, Qian YY, Chen N, Ling TJ, Wang JJ, Jiang H, et al. Detoxification of aflatoxin $B_{1}$ by Stenotrophomonas sp. CW117 and characterization the thermophilic degradation process. Environ Pollut. 2020;261:114178.

135. Wang LL, Wu J, Liu ZW, Shi YT, Liu JQ, Xu XF, et al. Aflatoxin B degradation and detoxification by Escherichia coli CG1061 isolated from chicken cecum. Front Pharmacol. 2019:9:1548.

136. Shu X, Wang YT, Zhou Q, Li MH, Hu H, Ma YH, et al. Biological degradation of aflatoxin $B_{1}$ by cell-free extracts of bacillus velezensis DY3108 with broad PH stability and excellent thermostability. Toxins (Basel). 2018;10(8):330.

137. Xia XH, Zhang Y, Li MY, Garba B, Zhang Q, Wang Y, et al. Isolation and characterization of a bacillus subtilis strain with aflatoxin $B_{1}$ biodegradation capability. Food Control. 2017;75:92-8.

138. Xu L, Ahmed MF, Sangare L, Zhao YJ, Selvaraj JN, Xing FG, et al. Novel aflatoxin-degrading enzyme from bacillus shackletonii L7. Toxins (Basel). 2017;9(1):36.

139. Raksha Rao K, Vipin AV. Hariprasad P, Anu Appaiah KA, Venkateswaran G. Biological detoxification of aflatoxin $B_{1}$ by bacillus licheniformis CFR1. Food Control. 2016;71:234-41

140. Samuel MS, Sivaramakrishna A, Mehta A. Degradation and detoxification of aflatoxin B1 by Pseudomonas putida. Int Biodeter Biodegr. 2014;86:202-9.

141. Farzaneh M, Shi ZQ, Ghassempour A, Sedaghat N, Ahmadzadeh M, Mirabolfathy $M$, et al. Aflatoxin $B_{1}$ degradation by Bacillus subtilis UTBSP1 isolated from pistachio nuts of Iran. Food Control. 2012;23(1):100-6.

142. Wang YX, Wang G, Dai YJ, Wang Y, Lee YW, Shi JR, et al. Biodegradation of deoxynivalenol by a novel microbial consortium. Front Microbiol. 2020;10: 2964

143. Jia R, Cao LR, Liu WB, Shen ZY. Detoxification of deoxynivalenol by Bacillus subtilis ASAG 216 and characterization the degradation process. Eur Food Res Technol. 2021:247:67-76.

144. Wang G, Wang YX, Ji F, Xu LM, Yu MZ, Shi JR, et al. Biodegradation of deoxynivalenol and its derivatives by Devosia insulae A16. Food Chem. 2019;276:436-42.

145. Zhai YY, Zhong L, Gao H, Lu ZX, Bie XM, Zhao HZ, et al. Detoxification of deoxynivalenol by a mixed culture of soil bacteria with 3-epi-deoxynivalenol as the main intermediate. Front Microbiol. 2019;10:2172.

146. Gao XJ, Mu PQ, Wen JK, Sun Y, Chen QM, Deng YQ. Detoxification of trichothecene mycotoxins by a novel bacterium, Eggerthella sp DII-9. Food Chem Toxicol. 2018:112:310-9.

147. He CH, Fan YH, Liu GF, Zhang HB. Isolation and identification of a strain of aspergillus tubingensis with deoxynivalenol biotransformation capability. Int J Mol Sci. 2008;9(12):2366-75.

148. Young JC, Zhou T, Yu H, Zhu HH, Gong JH. Degradation of trichothecene mycotoxins by chicken intestinal microbes. Food Chem Toxicol. 2007;45(1): 136-43. 
149. Fuchs E, Binder EM, Heidler D, Krska R. Structural characterization of metabolites after the microbial degradation of type A trichothecenes by the bacterial strain BBSH 797. Food Addit Contam. 2002;19(4):379-86.

150. Shima J, Takase S, Takahashi Y, Fujimoto H, Yamazaki M, Ochi K. Novel detoxification of the trichothecene mycotoxin deoxynivalenol by a soil bacterium isolated by enrichment culture. Appl Environ Microbiol. 1997; 63(10):3825-30.

151. Ju J, Tinyiro SE, Yao WR, Yu H. The ability of Bacillus subtilis and Bacillus natto to degrade zearalenone and its application in food. J Food Process Pres. 2019;43(10):e14122.

152. Wang G, Yu MZ, Dong F, Shi JR, Xu JH. Esterase activity inspired selection and characterization of zearalenone degrading bacteria Bacillus pumilus ES21. Food Control. 2017;77:57-64.

153. Xu JH, Wang HJ, Zhu ZW, Ji F, Yin XC, Hong Q, et al. Isolation and characterization of bacillus amyloliquefaciens ZDS-1: exploring the degradation of zearalenone by bacillus spp. Food Control. 2016;68:244-50.

154. Lei YP, Zhao LH, Ma QG, Zhang JY. Degradation of zearalenone in swine feed and feed ingredients by Bacillus subtilis ANSB01G. Duxbury Press. 2014; 7(2):143-51.

155. Zhao ZY, Zhang YM, Gong AD, Liu N, Chen SS, Zhao XY, et al. Biodegradation of mycotoxin fumonisin $B_{1}$ by a novel bacterial consortium SAAS79. Appl Microbiol Biotechnol. 2019;103(17):7129-40.

156. Benedetti R, Nazzi F, Locci R, Firrao G. Degradation of fumonisin $B_{1}$ by a bacterial strain isolated from soil. Biodegradation. 2006;17(1):31-8.

157. Styriak I, Conková E, Kmec V, Böhm J, Razzazi E. The use of yeast for microbial degradation of some selected mycotoxins. Mycotoxin Res. 2001; 17(Suppl1):24-7.

158. Camilo SB, Ono CJ, Ueno Y, Hirooka EY. Anti-Fusarium moniliforme activity and fumonisin biodegradation by corn and silage microflora. Bra Arch Biol Techn. 2000:43(2):159-64.

159. Smiley RD, Draughon FA. Preliminary evidence that degradation of aflatoxin $B_{1}$ by Flavobacterium aurantiacum is enzymatic. J Food Prot. 2000;63(3): 415-8.

160. Lillehoj EB, Stubblefield RD, Shannon GM, Shotwell OL. Aflatoxin $M_{1}$ removal from aqueous solutions by Flavobacterium aurantiacum. Mycopathol Mycol Appl. 1971;45(3):259-66.

161. Line JE, Brackett RE, Wilkinson RE. Evidence for degradation of aflatoxin $B_{1}$ by Flavobacterium aurantiacum. J Food Prot. 1994:57(9):788-91.

162. Gao X, Ma QG, Zhao LH, Lei YP. Isolation of Bacillus subtilis: screening for aflatoxins $B_{1}, M_{1}$, and $G_{1}$ detoxification. Eur Food Res Technol. 232(6):957-62

163. Cao H, Liu DL, Mo XM, Xie CF, Yao DS. A fungal enzyme with the ability of aflatoxin $B_{1}$ conversion: purification and ESI-MS/MS identification. Microbiol Res. 2011;166(6):475-83.

164. Yao D, Liu D, Guan M, Xie C. Detoxifizyme with activity of transforming aflatoxin and the gene encodes thereof. US Patent Publ. 2010; No. 7695751 B2.

165. Yehia SR. Aflatoxin detoxification by manganese peroxidase purified from Pleurotus ostreatus. Braz J Microbiol. 2014;45(1):127-33.

166. Zhao LH, Guan S, Gao X, Ma QG, Lei YP, Bai XM, et al. Preparation, purification and characteristics of an aflatoxin degradation enzyme from myxococcus fulvus ANSM068. J Appl Microbiol. 2011;110(1): $147-55$

167. Alberts JF, Gelderblom WC, Botha A, Zyl WH. Degradation of aflatoxin B (1) by fungal laccase enzymes. Int J Food Microbiol. 2009;135(1):47-52.

168. Tso KH, Lumsangkul C, Ju JC, Fan YK, Chiang $H$. The potential of peroxidases extracted from the spent mushroom (flammulina velutipes) substrate significantly degrade mycotoxin deoxynivaleno. Toxins (Basel). 2021;13(1):72.

169. He WJ, Shi MM, Yang P, Huang T, Zhao Y, Wu AB, et al. A quinonedependent dehydrogenase and two NADPH-dependent aldo/keto reductases detoxify deoxynivalenol in wheat via epimerization in a Devosia strain. Food Chem. 2020;321:126703

170. Carere J, Hassan YI, Lepp D, Zhou T. The enzymatic detoxification of the mycotoxin deoxynivalenol: identification of DepA from the DON epimerization pathway. Microb Biotechnol. 2018;11(6):1106-11.

171. Feltrin AC, Garcia SD, Caldas SS, Primel EG, Badiale-Furlong E, GardaBuffon J. Characterization and application of the enzyme peroxidase to the degradation of the mycotoxin DON. J Environ Sci Health B. 2017: 52(10):777-83
172. Ito M, Sato I, Ishizaka M, Yoshida S, Koitabashi M. Bacterial cytochrome P450 system catabolizing the Fusarium toxin deoxynivalenol. Appl Environ Microbiol. 2013;79(5):1619-28.

173. Shcherbakova L, Rozhkova A, Osipov D, Zorov I, Mikityuk O, Statsyuk N, et al. Effective zearalenone degradation in model solutions and infected wheat grain using a novel heterologous lactonohydrolase secreted by recombinant penicillium canescens. Toxins (Basel). 2020;12(8):475

174. Azam MS, Yu DZ, Liu N, Wu AB. Degrading ochratoxin A and zearalenone mycotoxins using a multifunctional recombinant enzyme. Toxins (Basel). 2019;11(5):301.

175. Masching S, Naehrer K, Karin N, Schwartz-Zimmermann HE, Sărăndan M,

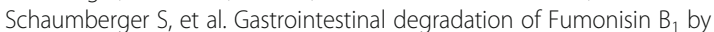
carboxylesterase FumD prevents fumonisin induced alteration of sphingolipid metabolism in turkey and swine. Toxins (Basel). 2016;8(3):84.

176. Karlovsky P, Crane EH, Gilliam JT, Maddox JR. Compositions and methods of zearalenone detoxification. US Patent:6812380.

177. Viksoe-Nielsen A, Birthe Hauerbach S. Process for degrading zearalenone in a feed product employing laccase. 2009; AU-A-2008337569.

178. Gradelet $S$, Le Bon AM, Bergès R, Suschetet $M$, Astorg P. Dietary carotenoids inhibit aflatoxin $B_{1}$-induced liver preneoplastic foci and DNA damage in the rat: role of the modulation of aflatoxin $B_{1}$ metabolism. Carcinogenesis. 1998; 19(3):403-11.

179. Xiao H, Tan BE, Wu MM, Yin YL, Li TJ, Yuan DX, et al. Effects of composite antimicrobial peptides in weanling piglets challenged with deoxynivalenol: II. Intestinal morphology and function. J Anim Sci. 2013;91(10):4750-6.

180. Ledur PC, Santurio JM. Cytoprotective effects of curcumin and silymarin on PK-15 cells exposed to ochratoxin $A$, fumonisin $B_{1}$ and deoxynivalenol. Toxicon. 2020;185:97-103.

181. Cao L, Zhang L, Zeng H, Wu RT, Wu TL, Cheng WH. Analyses of selenotranscriptomes and selenium concentrations in response to dietary selenium deficiency and age reveal common and distinct patterns by tissue and sex in telomere-dysfunctional mice. J Nutr. 2017;147(10):1858-66.

182. Zhao L, Sun LH, Huang JQ, Briens M, Qi DS, Xu SW, et al. A novel organic selenium compound exerts unique regulation of selenium speciation, selenogenome, and selenoproteins in broiler chicks. J Nutr. 2017:147(5):78997.

183. Nagaraj RY, Wu WD, Vesonder RF. Toxicity of corn culture material of fusarium proliferatum M-7176 and nutritional intervention in chicks. Poult Sci. 1994;73(5):617-26.

184. Tedesco D, Steidler S, Galletti S, Tameni M, Sonzgnoi O, Ravarotto L. Efficacy of silymarin-phospholipid complex in reducing the toxicity of aflatoxin $B_{1}$ in broiler chicks. Poult Sci. 2004;83(11):1839-43.

185. Cheng $P$, Ishfaq M, Yu H, Yang YQ, Li XT, Fazlani SA, et al. Curcumin ameliorates duodenal toxicity of $\mathrm{AFB}_{1}$ in chicken through inducing Pglycoprotein and downregulating cytochrome P450 enzymes. Poult Sci. 2020;99(12):7035-45

186. Li Y, Ma QG, Zhao LH, Guo YQ, Duan GX, Zhang JY, et al. Protective efficacy of alpha-lipoic acid against aflatoxin $B_{1}$-induced oxidative damage in the liver. Asian-Australas J Anim Sci. 2014;27(6):907-15.

187. Ghadiri S, Spalenza V, Dellafiora L, Badino P, Barbarossa A, Dall'Asta C, et al. Modulation of aflatoxin $B_{1}$ cytotoxicity and aflatoxin $M_{1}$ synthesis by natural antioxidants in a bovine mammary epithelial cell line. Toxicol Vitro. 2019;57: 174-83.

188. Sridhar M, Suganthi RU, Thammiaha V. Effect of dietary resveratrol in ameliorating aflatoxin $\mathrm{B}_{1}$-induced changes in broiler birds. J Anim Physiol Anim Nutr (Berl). 2015;99(6):1094-104.

189. Liu D, Guo WB, Yang JH, Zhao ZH, Liu JG. Protective effect of astragalus granules on the immunosuppression of BALB/C mice caused by deoxynivalenol. Chin Vet Sci. 2018.

190. Wang XM, Zuo ZC, Deng JL, Zhang Z, Chen CH, Fan Y, et al. Protective role of selenium in immune-relevant cytokine and immunoglobulin production by piglet splenic lymphocytes exposed to deoxynivalenol. Biol Trace Elem Res. 2018;184(1):83-91.

191. Atroshi F, Rizzo A, Biese I, Salonen M, Lindberg LA, Saloniem H. Effects of feeding T-2 toxin and deoxynivalenol on DNA and GSH contents of brain and spleen of rats supplemented with vitamin $E$ and $C$ and selenium combination. J Anim Phys Anim Nut. 2010;74(1-5):157-64.

192. Andretta I, Kipper M, Lehnen CR, Hauschild L, Vale MM, Lovatto PA. Metaanalytical study of productive and nutritional interactions of mycotoxins in growing pigs. Animal. 2012;6(9):1476-82. 
193. Wu MM, Xiao H. Yin YL, Li LL, Li TJ. Intervention effects of glutamic acid on the changes of growth performance, blood routine and serum biochemical indexes in deoxynivalenol stressed weaner piglets. Chin J Anim Nutr. 2013.

194. Xiao H, Wu MM, Tan BE, Yin YL, Li TJ, Xiao DF, et al. Effects of composite antimicrobial peptides in weanling piglets challenged with deoxynivalenol: I. Growth performance, immune function, and antioxidation capacity. J Anim Sci. 2013;91(10):4772-80.

195. Grosse Y, Chekir-Ghedira L, Huc A, Obrecht-Pflumio S, Dirheimer G, Bacha H, et al. Retinol, as-corbic acid and alpha-tocopherol prevent DNA adduct formation in mice treated with the mycotoxins ochratoxin A and zearalenone. Cancer Lett. 1997:114(1-2):225-9.

196. Gbore FA, Adu OA. Ameliorative potential of vitamin $E$ on the impact of dietary fumonisin $\mathrm{B} 1$ on reproductive performance of female rabbits. J Agr Rural Dev Trop. 2017;118(2):161-9.

197. Lu ZB. Dose-dependent fumonisin $B_{1}$ hepatotoxicity and hepatocarcinogenicity, detoxification of fumonisin $B_{1}$, and suppression by isoflavones of fumonisin $\mathrm{B}_{1}$-promoted hepatocarcinogenesis in rats. Dissertations Theses. 1997.

198. Klein PJ, Vleet T, Hall JO, Coulombe RA Jr. Dietary butylated hydroxytoluene protects against aflatoxicosis in Turkeys. Toxicol Appl Pharmacol. 2002; 182(1):11-9.

199. Solcan W, Gogu M, Floristean V, Oprisan B, Solcan G. The hepatoprotective effect of sea buckthorn (Hippophae rhamnoides) berries on induced aflatoxin $B_{1}$ poisoning in chickens. Poult Sci. 2013;92(4):966-74.

200. Chen MH, Yin J, Deng JW, Wu MM, Xiao H, Duan JL, et al. Interventional effects of amino acids on blood physiological and biochemical damages of fattening pigs induced by deoxynivalenol. Hunan Agric Sci. 2013.

Ready to submit your research? Choose BMC and benefit from:

- fast, convenient online submission

- thorough peer review by experienced researchers in your field

- rapid publication on acceptance

- support for research data, including large and complex data types

- gold Open Access which fosters wider collaboration and increased citations

- maximum visibility for your research: over $100 \mathrm{M}$ website views per year

At $\mathrm{BMC}$, research is always in progress.

Learn more biomedcentral.com/submissions 